Historic, archived document

Do not assume content reflects current scientific knowledge, policies, or practices. 
NATIONAL AGRICULTURAL LIBRARY

NATONAL AGR CULTURAL LBRARY

|| ||| I|| || || ||||||||||

1022499584 
p.2 Shortleaf Pine Bibliography

\begin{tabular}{|c|c|}
\hline $\begin{array}{l}\text { Compiled by } \\
\text { Glenn P. Haney }\end{array}$ & 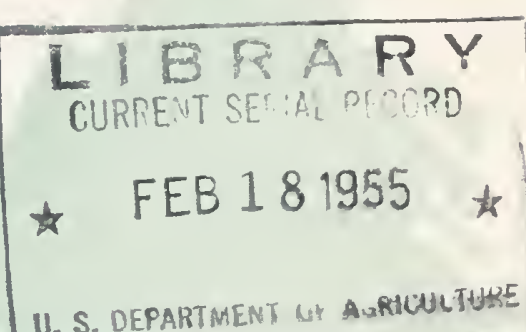 \\
\hline
\end{tabular}

SOUT-EASTERN FOREST

EXPERINENT STATION

Ashevile, North Carolina

$$
\begin{gathered}
\mathcal{E} \cdot \mathcal{L} \text { Demmon, } \\
\text { Director }
\end{gathered}
$$

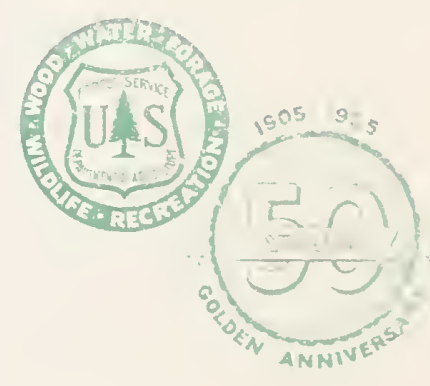




\section{FOREWORD}

In recent years forestry has gained a permanent position among the industries of the South and the importance of the southern pines, including shortleaf pine, has increased considerably. Until now there has been no complete collection of information about this species. The following collection of references, listed by subject matter and author, was compiled to fill this gap. It is hoped it will be useful to all foresters working with shortleaf pine.

The author wishes to acknowledge the many helpful suggestions from members of the Southeastern and other Experiment Stations, as well as from the USDA Library, Washington, D. C. Special acknowledgment is due to Keith W. Dorman and Ivan H. Sims, whose Loblolly Pine Bibliography served as a guide for this publication. 
GENERAL REFERENCES . . . . . . . . . . . .

Monographs on the species - Identification -

Geographic distribution - Forest survey volume

and growth data - Reports on forests by state.

FOREST MANAGEMENT . . . . . . . . . . . . . .

Growth of stands - Thinning - Pruning -

Management systems - Financial aspects -

Mortality - Logging damage - Use of fire.

ECOLOGY AND PHYSIOLOGY . . . . . . . . . . . .

Plant succession - Plant associates -

Hardwood invasion of pine stands -

Nutritional requirements - Site index

factors - Site classification - Comparative

tolerance - Chemical composition of needles

and wood - Effect of mycorrhiza - Normal

growth of roots and tops - Drought resistance.

REGENERATION ....................

Seed handling - Seed storage - Nursery practice -

Mycorrhiza on seedlings - Growth of seedlings -

Planting - Planting outside natural range - Planting

for erosion control - Direct seeding - Natural

regeneration - Seed tree selection - Seedbed

preparation - Seed production.

UTILIZATION . . . . . . . . . . . . . . . . .

Characteristics and properties of wood - Uses -

Identification of wood - Pulpwood paper manufacture -

Effect of fungi on wood and wood products -

Preservative treatments - Seasoning of wood.

FUNGUS DISEASES . . . . . . . . . . . . . .

Rust cankers - Heartrot - Littleleaf - Needle

cast - Needle blight - Needle rusts - Root rot -

Effect of fire on decay.

MENSURATION . . . . . . . . . . . . . . . . .

Tables for stands, yields, volume, and taper -

Site index curves - Converting factors for

pulpwood - Volume weight ratio of logs -

Stacked and solid volume of pulpwood -

Tree and log grades. 
EFFECT ON SOIL ..................... 51

Chemical composition of litter - Effect on soil profiles - Use as a soil builder - Effectiveness in erosion control.

EFFECT OF FIRE .................... 53

Effect on growth, stands, cull, mortality, and plant succession - Use of prescribed fire.

INSECT ENEMIES ................... 54 Borers - Bark beetles - Sawflys - Tip moths.

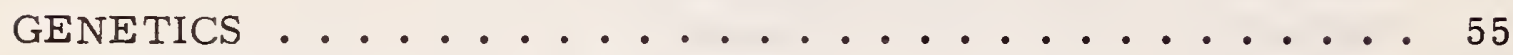

Natural variation - Effect of source of seed on growth - Hybridization - Inheritance of characteristics - Flower production Vegetative propagation.

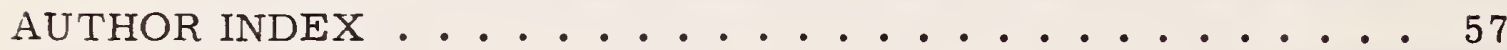




\title{
SHORTLEAF PINE BIBLIOGRAPHY
}

\author{
Compiled by \\ Glenn P. Haney \\ Piedmont Research Center, Union, S. C.
}

Shortleaf pine, Pinus echinata, Mill., is one of the four pine species commonly referred to as southern yellow pine. It comprises about one-fourth of the total volume of pine timber in the South. Its botanical range extends from New Jersey to Texas and Oklahoma, occurring in some 22 states. Shortleaf pine is commercially important in the Piedmont region of Virginia, North Carolina, South Carolina, and Georgia; in the northern portions of Alabama and Mississippi; along the western foothills of the Appalachians in Tennessee, Kentucky, and West Virginia; and in eastern Texas, southeastern Oklahoma, southwestern Arkansas, and northwestern Louisiana. In recent years shortleaf pine has become an important planting species in southern Indiana, Illinois, and Missouri. This bibliography was prepared in order to gather together a list of the many references pertaining to this species. It covers the literature approximately from 1900 to June 1954.

Information concerning shortleaf pine may be found in a wide variety of publications including technical journals, trade journals, and farm magazines. Some articles therefore are of a popular nature, while others are technical accounts of research studies. Readers having a general knowledge of the periodicals will be able to estimate whether treatment is technical or popular.

The subject matter divisions have been made rather broad in order to keep the bibliography as simple as possible. The divisions used are the same as those used in the Loblolly Pine Bibliography published by the Station in 1949. All citations appear in each division in alphabetical order by author. The final section is an alphabetical author list.

In compiling this bibliography, a reference was not cited more than twice. For example, an article on the effects of fire on reproduction appears under the head Effect of Fire as well as under Regeneration. Tables of volume growth, and yield appear under both Forest Management and Mensuration. Monographs on the species appear under General References.

Every effort was made to include all the references for shortleaf pine in this bibliography, but it is possible that some omissions were made. Comments and suggestions will therefore be appreciated. 


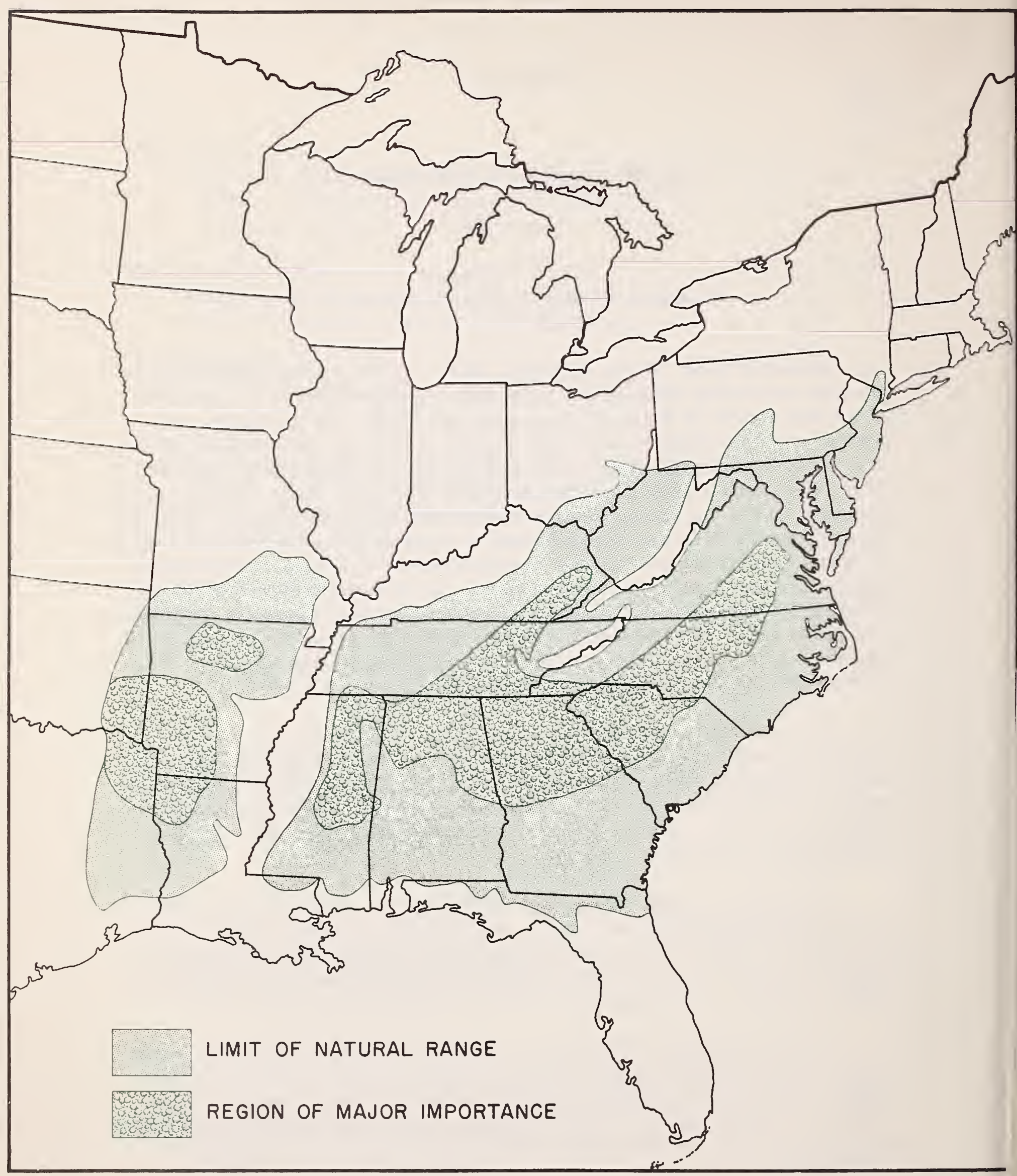

Figure 1.--Range of shortleaf pine, showing the limit of its natural range and its region of major importance. 


\section{GENERAL REFERENCES}

Monographs on the species - Identification -

Geographic distribution - Forest survey volume

and growth data - Reports on forests by state.

Anon.

Shortleaf pine (Pinus echinata Mill.). Amer. Forests 40(7):316-317. 1934.

Beilmann, August P.

Scouting the shortleaf pine. Missouri Bot. Gard. Bul. 28(5): 97-101. 1940.

Betts, H. S.

The southern pines. U. S. Forest Serv. American Woods Series. 13 pp. 1945.

Craig, Ronald B.

Virginia forest resources and industries. U. S. Dept. Agri. Misc. Pub. 681. 64 pp. 1949.

Cruikshank, J. W.

Forest resources in the Tennessee Valley of North Alabama. Southern

Forest Expt. Sta. Forest Survey Release 49. 39 pp. 1940.

Cruikshank, J. W.

Forest resources of the Southern Coastal Plain of North Carolina.

Appalachian Forest Expt. Sta. Forest Survey Release 4. 46 pp. 1940.

Cruikshank, J. W.

Forest resources of the Northern Coastal Plain of North Carolina.

Appalachian Forest Expt. Sta. Forest Survey Release 5. 48 pp. 1940.

Cruikshank, J. W.

Forest resources of the Piedmont region of North Carolina. Appalachian

Forest Expt. Sta. Forest Survey Release 6. 55 pp. 1940.

Cruikshank, J. W.

Forest resources of the mountain region of North Carolina. Appalachian

Forest Expt. Sta. Forest Survey Release 7. 55 pp. 1941.

Cruikshank, J. W.

The forest situation in the Coastal Plain of Virginia. Appalachian Forest

Expt. Sta. Forest Survey Release 12. 71 pp. 1943.

Cruikshank, J. W.

North Carolina forest resources and industries. U. S. Dept. Agr. Misc.

Pub. 533. 76 pp. 1944.

Cruikshank, J. W.

Southern forests as a source of pulpwood. Southeastern Forest Expt. Sta.

Forest Survey Release 22. 12 pp. 1947. 
Cruikshank, J. W., and Eldredge, I. F.

Forest resources of southeastern Texas. U. S. Dept. Agr. Misc. Pub. 326. 37 pp. 1939.

Cruikshank, J. W., and Toler, A. D.

North Carolina forest growth and drain, 1937-1943. Appalachian Forest

Exp. Sta. Forest Survey Release 18. 36 pp. 1945.

Cruikshank, J. W.

Forest resources of north central Alabama. Southern Forest Expt. Sta.

Forest Survey Release 50. 36 pp. 1940.

Detwiler, Samuel B.

Shortleaf pine: identification and characteristics. Amer. Forests 22(273): 513-517. 1916.

Duerr, W. A., Evans, Thomas C., and Morrill, G. E.

The forest situation in Piedmont Virginia. Appalachian Forest Expt. Sta.

Forest Survey Release 13. 83 pp. 1943.

Eldredge, I. F.

Southern forests, then and now. Jour. Forestry 50(3): 182-185. 1952.

Evans, Thomas C.

The distribution of commercial forest trees in Virginia. Appalachian Forest

Expt. Sta. Forest Survey Release 10. 32 pp. 1942.

Faulks, E. B.

Forest resources of the Northern Coastal Plain of South Carolina. Appalachian

Forest Expt. Sta., Forest Survey Release 1. 30 pp. 1939.

Forest Products Laboratory

Southern yellow pine. U. S. Forest Serv., Forest Prod. Lab. Tech. Note 214. 8 pp. 1936.

Frothingham, E. H., and Nelson, Ralph M.

South Carolina forest resources and industries. U. S. Dept. Agr. Misc. Pub. 552. 72 pp. 1944.

Greaves, B.

Greaves, B.

Shortleaf pine. South. Lumberman 129(1681): 297-298. 1927.

Harper, R. M.

Economic botany of Alabama, Part 1. Georgraphical report, including descriptions of the natural divisions of the state (Alabama), their forests and forest industries with quantitative analyses and statistical tables. Ala. Geol. Survey Monog. 8. 228 pp. 1913.

Harper, R. M.

Economic botany of Alabama, Part 2. Catalogue of the trees, shrubs, and vines of Alabama, with their economic properties and local distribution. Ala. Geol. Survey Monog. 9. 357 pp. 1928. 
Harper, R. M.

Forests of Alabama. Ala. Geol. Survey Monog. 10. 230 pp. 1943.

Hicks, W. T.

Forest resources of the Piedmont region of South Carolina. Appalachian

Forest Expt. Sta. Forest Survey Release 2. 31 pp. 1939.

James, L. M.

Mississippi's forest resources and industries. U. S. Dept. Agr. Forest

Resource Rpt. 4. 92 pp. 1951.

Koehler, Arthur

Guidebook for the identification of woods used for ties and timbers. U. S.

Dept. Agr. Forest Serv. Misc. RL-1. 79 pp. 1917.

Larson, Robert W.

The timber supply outlook in South Carolina. U. S. Dept. Agr. Forest

Resource Rpt. 3. 66 pp. 1951.

Liming, Franklin G.

The range and distribution of shortleaf pine in Missouri. Central States

Forest Expt. Sta. Tech. Paper 106. 4 pp. 1946.

Lotti, Thomas, and Evans, Thomas C.

Virginia's forests. Appalachian Forest Expt. Sta. Forest Survey Release

11. 75 pp. 1942 .

Lotti, Thomas, and Evans, Thomas C.

The forest situation in the mountain region of Virginia. Appalachian Forest

Expt. Sta. Forest Survey Release 15. 1943.

Lowe, E.N.

Plants of Mississippi. Miss. State Geol. Survey Bul. 17. 292 pp. 1921.

Maryland State Board of Forestry

Shortleaf pine. Maryland State Board of Forestry Leaflet 30. 4 pp. 1922.

Mattoon, Wilbur R.

Life history of shortleaf pine. U. S. Dept. Agr. Bul. 244. 46 pp. 1915.

Mattoon, Wilbur R.

Shortleaf pine: its economic importance and forest management. U. S.

Dept. Agr. Bul. 308. 67 pp. 1915.

Mattoon, Wilbur R.

Shortleaf pine. U. S. Dept. Agr. Farmers'Bul. 1671. 43 pp. Rev. 1940.

McCormack, James F.

Forest statistics for southwest Georgia, 1951. Southeastern Forest Expt.

Sta. Forest Survey Release 37. 38 pp. 1952. 
McCormack, James F.

Forest statistics for southeast Georgia, 1952. Southeastern Forest Expt.

Sta. Forest Survey Release 39. 38 pp. 1952.

McCormack, James F.

Forest statistics for central Georgia, 1952. Southeastern Forest Expt. Sta.

Forest Survey Release 40. 44 pp. 1953.

McCormack, James F.

Forest statistics for southern coastal plain of North Carolina, 1952.

Southeastern Forest Expt. Sta. Forest Survey Release 4l. 45 pp. 1953.

McCormack, James F., and Cruikshank, J. W.

South Carolina's forest resources, 1947. Southeastern Forest Expt. Sta.

Forest Survey Release 28. 122 pp. 1949.

Mohr, Charles

The timber pines of the southern United States. U. S. Dept. Agr. Div.

Forestry Bul. 13, rev. 176 pp. 1897.

Munns, E. N.

The distribution of important forest trees of the United States. U. S. Dept.

Agr. Misc. Pub. 287. 178 pp. 1938.

Perry, George S.

Distribution of shortleaf pine in Pennsylvania. Forest Leaves 19(9):134-135. 1924.

Pinchot, Gifford, and Ashe, W. W.

Timber trees and forests of North Carolina. U. S. Geol. Survey Bul. 6.

227 pp. 1897.

Record, Samuel J.

The forests of Arkansas. Forestry Quarterly 5(3): 296-301. 1907.

Roberts, E. V., and Cruikshank, J. W.

The distribution of commercial forest trees in North Carolina. Appalachian

Forest Expt. Sta. Forest Survey Release 8. 27 pp. 1941.

Roberts, E. V., and Cruikshank, J. W.

The distribution of forest trees in South Carolina. Appalachian Forest

Expt. Sta. Forest Survey Release 9. 20 pp. 1941.

Shaw, G. R.

The genus pinus. Arnold Arboretum Pubs. 5. Cambridge, Riverside Press. 96 pp. 1914.

Southeastern Forest Experiment Station

Southern Forest Experiment Station

Atlas of economic information for the south. Southern and Southeastern

Forest Experiment Stations. 1950.

Southern Forest Experiment Station, Forest Survey Staff

Forest resources of southwest Arkansas. Forest Survey Release 27. 21 pp.

1937. 
Southern Forest Experiment Station, Forest Survey Staff

Forest resources of southwest Alabama. Forest Survey Release 35. 35 pp. 1938.

Southern Forest Experiment Station, Forest Survey Staff

Forest resources of the Ouachita mountain region of Arkansas. Forest

Survey Release 36.27 pp. 1938.

Southern Forest Experiment Station

Forest statistics for the Arkansas Ozarks. Forest Survey Release 57. 23 pp. 1948.

Southern Forest Experiment Station

Forest statistics for Mississippi. Forest Survey Release 59. 67 pp. 1949.

Southern Forest Experiment Station

Forest statistics for western and central Tennessee. Forest Survey

Release 63. 27 pp. 1949.

Southern Forest Experiment Station

Forest statistics for southwest Arkansas. Forest Survey Release 65. 21 pp. 1950 .

Southern Forest Experiment Station

Forest statistics for eastern Tennessee. Forest Survey Release 66. 25 pp. 1951.

Southern Forest Experiment Station

Forest statistics for Tennessee. Forest Survey Release 70. 56 pp. 1952.

Spillers, A. R.

Forest resources of southeast Alabama. Southern Forest Expt. Sta. Forest Survey Release 47. 32 pp. 1939.

Spillers, A. R.

Forest resources of west central Alabama. Southern Forest Expt. Sta.

Forest Survey Release 48.30 pp. 1940.

Spillers, A. R., and Eldredge, I. F.

Georgia forest resources and industries. U. S. Dept. Agr. Misc. Pub. 501. 70 pp. 1943.

Sternitzke, H. S., and Duerr, W. A.

Tree distribution in Mississippi. Southern Forest Expt. Sta. Forest Survey Release 64. 19 pp. 1950.

U. S. Tennessee Valley Authority. Dept. Forestry Relations Forestry data for the Tennessee Valley. Part I. Area data for valley counties. U. S. Tennessee Valley Authority Forestry Bul. 3. 155 pp. 1943. 


\section{General References}

Weidman, R. H.

Trees in the Eddy Arboretum. California Forest and Range Expt. Sta. Research Note 53. 8 pp. 1947.

Winters, R. K., Ward, G. B., and Eldredge, I. F.

Louisiana forest resources and industries. U. S. Dept. Agr. Misc. Pub. 519. 44 pp. 1943. 


\section{FOREST MANAGEMENT}

Growth of stands - Thinning - Pruning Management systems - Financial aspects Mortality - Logging damage - Use of fire.

Ashe, W. W.

Management of loblolly and shortleaf pines. Soc. Amer. Foresters Proc. 5(1): 84-100. 1910.

Ashe, W. W.

The use of cut-over shortleaf pine lands. Amer. Lum. (1872): 43-44. 1911.

Ashe, W. W.

Shortleaf pine in Virginia; the increase in its yield by thinning. Va. Dept. Agr. and Immigr. 44 pp. 1913.

Ashe, W. W.

Loblolly; or North Carolina pine. N. C. Geol. and Econ. Survey Bul. 24. 176 pp. 1915.

Ashe, W. W.

Profit or loss in cutting shortleaf and loblolly pines in Alabama. Ala. State Comm. Forestry Bul. 2. 64 pp. 1928.

Baker, Frederick S.

A revised tolerance table. Jour. Forestry 47(3): 179-181. 1949.

Barrett, Leonard I.

Observations on requirements for restocking cutover loblolly and shortleaf pine stands. Appalachian Forest Expt. Sta. Tech. Note 42. 9 pp. 1940.

Barrett, Leonard I.

Requirements for restocking cutover loblolly and shortleaf pine stands. South. Lumberman 161 (2033): 200-202. Dec. 1940.

Barrett, Leonard I., and Righter, F. I.

Working plan for experimental thinnings in shortleaf and loblolly pines. Jour. Forestry 27(7): 782-803. 1929.

Beal, J. A.

Mortality of reproduction defoliated by the red-headed pine sawfly

(Neodiprion lecontei Fitch). Jour. Forestry 40(7): 562-563. 1942.

Boggess, W. R.

Diameter growth of shortleaf pine (Pinus echinata) and white oak (Quercus alba) during a dry season. Univ. Ill. Agr. Expt. Sta. Forestry Note 37.7 pp. 1953. 
Boggess, W. R., and Lorenz, R. W.

Growth and early thinning of shortleaf pine (Pinus echinata Mill.) in southern Illinois. Univ. Ill. Agr. Expt. Sta. Forestry Note 16. 2 pp. 1950.

Boggess, W. R., and McMillan, F. W.

First thinning yields from a 15 year old shortleaf pine plantation in southern Illinois. Univ. Ill. Agr. Expt. Sta. Forestry Note 36. 2 pp. 1953.

Boggess, W. R., and Newman, R. R.

Occurrence of littleleaf disease of pine and its effects on forestry in Alabama. Ala. Agr. Expt. Sta. Cir. 94. 11 pp. 1947.

Bond, W. E.

Cost and returns of managing 100,000 acres of shortleaf and loblolly pine for sustained yield. Southern Forest Expt. Sta. Occas. Paper 79. 15 pp. 1939.

Bond, W. E.

Case for all-aged management of southern pines. Jour. Forestry 51(2): 90-93. 1953.

Bond, W. E., Wahlenberg, W. G., and Kirkland, Burt P.

Profitable management of shortleaf and loblolly pine for sustained yield. South. Lumberman 155(1961): 129-140. 1937. Southern Forest Expt. Sta. Occas. Paper 70. 37 pp. 1937.

Buell, Jesse H.

Outside-bark form class volume tables for some southern Appalachian species. Appalachian Forest Expt. Sta. Tech. Note 53. 76 pp. 1942.

Buell, Jesse H.

Results of C. C. C. timber stand improvement on Southern Appalachian National Forests. Jour. Forestry 41(2): 105-112. 1943.

Bull, Henry

Profit from improving a second-growth forest of loblolly and shortleaf pines and hardwoods. Southern Forest Expt. Sta. Occas. Paper 38. 8 pp. 1934.

Bull, Henry

Thinning loblolly pine in even-aged stands. Jour. Forestry 33(5): 513-518. 1935.

Bull, Henry

Pulpwood yields from experimental thinnings in old field stands of loblolly and shortleaf pines. Southern Forest Expt. Sta. Occas. Paper 57. 9 pp. 1936.

Bull, Henry

Increased growth of loblolly pine as a result of cutting and girdling large hardwoods. Jour. Forestry 37(8): 642-645. 1939. 
Bull, Henry, Williams, Edward B., and Judson, George M.

Harvest-cutting studies in east Texas loblolly and shortleaf pine. South.

Lumberman 177(2225): 282, 284-286, 288. 1948.

Burns, Joe Dae

Some effects of forest fires on mortality and growth of certain species of southern pines. (Abs.) Jour. Forestry 47(7): 554. 1949.

Byram, G. M., and Doolittle, W. T.

A year of growth for a shortleaf pine. Ecology 31(1): 27-35. 1950.

Campbell, W. A., Copeland, O. L., Jr., and Hepting, George H.

Managing shortleaf pine in littleleaf disease areas. Southeastern Forest

Expt. Sta. Paper 25. 12 pp. 1953.

Chamberlin, H, H. , Sample, L. A., and Hayes, R. W.

Private forest land ownership and management in the loblolly-shortleaf type in southern Arkansas, northern Louisiana, and central Mississippi.

La. Agr. Expt. Sta. Bul. 393. 46 pp. 1945.

Chapman, Arthur G.

Survival and growth of various grades of shortleaf pine planting stock.

Iowa State College Jour. Science 22(4): 323-331. 1948.

Chapman, H. H.

Is selective cutting a panacea for forest regulation? Jour. Forestry 42(5):

345-347. 1944.

Clark, Stuart F.

Forest enemy number two. South. Lumberman 175(2201): 182-184. 1947.

Clark, Stuart F., and Hebb, Edwin A.

Mortality in pine stands during first year after logging. South. Lumberman 183(2297): 256, 258. 1951.

Coile, T. S.

The effect of rainfall and temperature on the annual radial growth of pine in the Southern United States. Ecol. Monog. 6(4): 533-562. 1936.

Cruikshank, J. W.

Site index of the major pine forest types in the Southeast. Southeastern

Forest Expt. Sta. Res. Note 50. 1954.

Cummings, William $\mathrm{H}$.

Early effects of pruning in a young shortleaf pine planting. Jour. Forestry 40(1): 61-62. 1942 .

Curran, C. E.

Relation of growth characteristics of southern pine to its use in pulping. Jour. Forestry 36(6): 576-581. 1938. U. S. Forest Prod. Lab. R 1168. 11 pp. 1938. 
Dingle, R. W.

Survival and growth of forest plantations in Missouri. Jour. Forestry 50(11): 845-849. 1952 .

Dunlap, Frederick

Forestry problems in shortleaf pine. Southern Forestry Cong. Proc.

7: $50-52$. 1925.

Emmer, R. E.

Volume table for shortleaf pine. Central States Forest Expt. Sta. Tech. Note 42.1 p. 1941.

Flick, Frances J.

Bibliography: Management of loblolly-shortleaf pine - hardwood forests.

U. S. Dept. Agr. Library. Processed by Southern Forest Expt. Sta. 7 pp. 1947.

Folweiler, A. D.

The place of fire in southern silviculture. Jour. Forestry 50(3):187-190. 1952.

Folweiler, A. D., and Vaux, H. J.

Private forest land ownership and management in the loblolly-shortleaf

type of Louisiana. Jour. Forestry 42(11): 783-790. 1944.

Forbes, R. D.

Timber growing and logging and turpentining practices in the southern pine region. U. S. Dept. Agr. Tech. Bul. 204. 115 pp. 1930.

Forbes, R. D., and Bruce, Donald

Rate of growth of second-growth southern pines in full stands. U. S. Dept. Agr. Cir. 124. 77 pp. 1930.

Garin, G. I.

Establishment of loblolly and shortleaf pine reproduction on a clear-cut

strip. Jour. Ala. Acad. Sci. 21/22: 20-23. 1952.

Garver, R.D., and Miller, R. H.

Selective logging in the shortleaf and loblolly pine forests of the Gulf States region. U. S. Dept. Agr. Tech. Bul. 375. 53 pp. 1933.

Gibbs, J. A.

Tree plantings control erosion and produce wood. Forest Farmer 8(2): 5. 1948 .

Girard, James W.

Volume tables for Mississippi bottomland hardwoods and southern pines.

Jour. Forestry 31(1): 34-41. 1933.

Grano, C. X.

Wind-firmness of shortleaf and loblolly pines. South. Lumberman 187 (2345):

116. 1953. 
Grano, C. X.

Re-establishment of shortleaf-loblolly pine under four cutting methods.

Jour. Forestry 52(2): 132-133. 1954.

Guttenberg, S.

Growth and mortality in an old-field southern pine stand. Jour. Forestry 52(3): $166-168.1954$.

Guttenberg, S., and Reynolds, R. R.

Cutting financially mature loblolly and shortleaf pine. Southern Forest

Expt. Sta. Occas. Paper 129. 18 pp. 1953.

Hall, William L.

Building up a shortleaf-loblolly forest in Arkansas. Jour. Forestry 37(7): 538-540. 1939.

Hargreaves, L. A.

Relationship between density and basal area of natural shortleaf pine stands in the Georgia Piedmont. Unpublished thesis, Univ. of Georgia. (Abs.) Jour. Forestry 46(4): 318. 1948.

Hepting, George $\mathrm{H}$.

Littleleaf - a shortleaf and loblolly pine problem. Amer. Forests 50(5): 244. 1944.

Hepting, George $\mathrm{H}$.

The littleleaf disease of pine: how to prevent its ravages. Plants and Gardens (n.s.) 7(2): 153-154. 1951.

Hepting, George H., and Chapman, A. Dale

Losses from heart rot in two shortleaf and loblolly pine stands. Jour. Forestry 36(12): 1193-1201. 1938.

Hepting, George H., and Jemison, George M.

Cure for littleleaf disease? Amer. Forests 56(11): 20-22. 1950.

Hetrick, L. A.

Some observations of Ips bark beetle attack on pine trees. Jour. Econ.

Ent. 35(2): 181-183. 1942 .

Huberman, M. A.

Normal growth and development of southern pine seedlings in the nursery.

Ecology 21(3): 323-334. 1940.

Huckenpahler, B.J.

Loblolly pine is superior to shortleaf. Miss. Farm Res. 11(7): 8. 1948.

Huckenpahler, B. J.

Which is best? A study of loblolly vs. shortleaf. South. Lumber Jour. 53(3): $19,108.1949$.

Huckenpahler, B. J.

Development of nineteen-year-old southern pine plantations in Tennessee.

Jour. Forestry 48(10): 722-723. 1950. 
Jemison, George M., et al.

Cutting practices for the Carolinas. Jour. Forestry 43(12): 861-870. 1945.

Kellogg, L. F., and Kuenzel, J.G.

Lumber grade recovery from shortleaf pine and mixed oak in northern

Arkansas. Jour. Forestry 43(1): 10-15. 1945.

Koehler, Arthur

Rapid growth hazards usefulness of southern pine. Jour. Forestry 36(2): 153-158. 1938.

Korstian, C.larence F., and Coile, T. S.

Plant competition in forest stands. Duke Univ. School of Forestry Bul. 3. $125 \mathrm{pp} .1938$.

Kozlowski, Theodore Thomas

Light and water in relation to growth and competition of Piedmont forest tree species. Ecol. Monog. 19(3): 207-231. 1949.

Lane, R. D., and Liming, Franklin G.

Some effects of release on planted shortleaf pine in the Missouri Ozarks.

Central States Forest Expt. Sta. Note 37. 6 pp. 1939.

Lange, Keith D.

Effects of clearcutting understory hardwoods on the growth of a shortleaf-

Virginia pine stand. Jour. Forestry 49(3): 176-178. 1951.

Lange, Keith D.

Guide for first thinning of plantations of loblolly and shortleaf pine.

U. S. Tennessee Valley Authority Tech. Note 9.9 pp. 1952.

Lemieux, F. J.

Log rules, taper tables, and volume tables for use in the south. Jour.

Forestry 34(10): 970-974. 1936.

Liming, Franklin G.

Natural regeneration of shortleaf pine in the Missouri Ozarks. Jour.

Forestry 43(5): 339-345. 1945.

Liming, Franklin G.

Response of planted shortleaf pine to overhead release. Central States

Forest Expt. Sta. Tech. Paper 105. 20 pp. 1946.

Limstrom, G. A., and Deitschman, G. H.

Early response to thinning of shortleaf pine in Indiana. Central States

Forest Expt. Sta. Note 82. 1953.

Lindgren, Ralph M.

Care needed in thinning pines with heavy fusiform rust infection. Forest

Farmer 7(12): 3. 1948. 
Mann, William F., Jr.

Profits from release of loblolly and shortleaf pine seedlings. Jour. Forestry 49(4): 250-253. 1951.

Marckworth, Gordon D.

Farm forestry in the shortleaf pine section of east Texas. Texas A \& $M$

College, Dept. of Forestry Bul. 10. 19 pp.

Matte, Lorenzo

Pulpwood volume tables for southeastern pines. Unpublished thesis,

Duke Univ. 1944.

Mattoon, Wilbur R.

The sprouting of shortleaf pine in the Arkansas National Forest. Forestry Quarterly 6(2): 158-159. 1908.

Mattoon, Wilbur R.

Growth of shortleaf pine (Pinus echinata Mill.) planted in District of

Columbia and New Jersey. Jour. Forestry 21(3): 284-285. 1923.

Mattoon, Wilbur R.

Pruning southern pines. U. S. Dept. Agr. Farmers' Bulletin 1892. 34 pp. 1942.

McCulley, R. D.

Case for even-aged management of southern pine. Jour. Forestry 51(2):

88-90. 1953 .

Mesavage, Clement

New tables for estimating board-foot volume of timber. South. Lumberman 173(2177): $153-156.1946$.

Mesavage, Clement

Board-foot volume tables for southern lumbermen. South. Lumberman

175(2201): 195-197. 1947 .

Mesavage, Clement

Tables for estimating cubic-foot volume of timber. Southern Forest Expt.

Sta. Occas. Paper 111. 71 pp. 1947.

Mesavage, Clement, and Girard, James W.

Tables for estimating board-foot volume of timber. U. S. Dept. Agr.

Forest Serv. 94 pp. 1946.

Meyer, Walter H.

Diameter distribution series in even-aged forest stands. Yale Univ.

School of Forestry. Bul. 28. 105 pp. 1930.

Minckler, Leon S.

Effect of rainfall and site factors on the growth and survival of young

forest plantations. Jour. Forestry 41(11): 829-833. 1943. 
Minckler, Leon S.

Early results from a reforestation pilot plant. Jour. Forestry 42(8): 586-590. 1944.

Minckler, Leon S.

Planted pines on clay pan soils of southern Illinois. Central States Forest Expt. Sta. Note 44.1948.

Minckler, Leon S.

Poor oak sites may grow good pine. Central States Forest Expt. Sta. Tech. Paper 134. 6 pp. 1953.

Minckler, Leon S., and Chapman, Arthur G.

Direct seeding of pines in the central hardwoods region. Central States

Forest Expt. Sta. Tech. Paper 140. 20 pp. 1954.

Minor, C. O.

Form class volume tables for use in southern pine pulpwood timber estimating. La. Agr. Expt. Sta. Bul. 445. 39 pp. 1950.

Moberg, T. R.

Silviculture of southern pines from the stand point of growing sawlogs; summary. Jour. Forestry 51(2): 94. 1953.

Ordel, Arthur W., Jr.

A comparison of growth and yields of some young loblolly pine and shortleaf pine plantations in the Duke Forest. Unpublished thesis, Duke Univ. 1949.

Paul, Benson $\mathrm{H}$.

The application of silviculture in controlling the specific gravity of wood.

U. S. Dept. Agr. Tech. Bul. 168. 20 pp. 1930.

Paul, Benson $\mathrm{H}$.

Mixed stands produce pine lumber of higher grades. South. Lumber Jour. 37(4): 26. 1933.

Paul, Benson $\mathrm{H}$.

Knots in second-growth pine and the desirability of pruning. U.S. Dept. Agr. Misc. Pub. 307. 35 pp. 1938.

Perry, George S.

Management of shortleaf pine. Pa. Dept. Forests and Waters, Serv.

Letter Ser. 6(7): 2-3. 1935.

Reynolds, R. R.

Forest management in shortleaf-loblolly pine regions of the South. Ames

Forester 25: 27-33. 1937.

Reynolds, R. R.

Pulpwood production studies in shortleaf-loblolly pine stands. Southern

Forest Expt. Sta. Occas. Paper 71. 5 pp. 1937.

Reynolds, R. R.

Studies of pulpwood production in shortleaf-loblolly pine stands. Paper

Trade Jour. 106(17): 64-65. 1938. 
Reynolds, R. R.

Improvement cuttings in shortleaf and loblolly pine. Jour. Forestry 37(7):

568-570. 1939. Southern Forest Expt. Sta. Occas. Paper 81. 4 pp. 1939.

Reynolds, R. R.

Management of second-growth shortleaf-loblolly pine-hardwood stands.

Jour. Forestry 45(3): 181-187. 1947.

Reynolds, R. R.

Some results of forest management research at the Crossett Experimental

Forest. Assoc. of Southern Agr. Workers, Forestry Section Symposium.

9 pp. 1949.

Reynolds, R. R.

Sidelights on managing mixed pine-hardwood stands under the selection

system. Jour. Forestry 48(2): 108-111. 1950.

Reynolds, R. R.

Pulpwood production costs in southeast Arkansas, 1950. Southern

Forest Expt. Sta. Occas. Paper 121.17 pp. 1951.

Reynolds, R. R.

Pulpwood production costs and methods in southeastern Arkansas. South.

Pulp and Paper Manufacturer 14(9): 28, 30, 32. 1951.

Reynolds, R. R.

Improvement cutting in shortleaf and loblolly pine. South. Lumberman

183(2297): 237-239. 1951.

Reynolds, R. R.

Are suppressed pines inferior? South. Lumberman 185(2321): 182-183.

1952.

Reynolds, R. R., Bond, W. E., and Kirkland, Burt P.

Financial aspects of selective cutting in the management of second-growth pine-hardwood forests west of the Mississippi River. U. S. Dept. Agr.

Tech. Bul. 861. 118 pp. 1944.

Roth, Elmer R., Buchanan, Thomas S., and Hepting, George H.

A five-year record of littleleaf on thirty-one plots. Bur. Plant Indus.

Soils, Agr. Engin., Forest Path. Spec. Release 32.9 pp. 1948.

Rothacher, Jack S.

Percentage distribution of tree volume by logs. Jour. Forestry 46(2):

115-118. 1948 .

Schumacher, F. X.

Stacked and solid volume of southeastern pulpwood. Jour. Forestry 44(8):

579-582. 1946. 
Siggers, Paul V.

Slash disposal methods in logging shortleaf pine. Southern Forest Expt.

Sta. Occas. Paper 42. 5 pp. 1935.

Smith, Lloyd F.

Early results of a liberation cutting in a pine-hardwood stand in Northern

Louisiana. Jour. Forestry 45(4): 278-282. 1947.

Somes, H. A., and Moorhead, G. R.

Prescribed burning does not reduce yield from oak-pine stands of southern

New Jersey. Northeastern Forest Expt. Sta. Paper 36. 19 pp. 1950.

Southeastern Forest Experiment Station

Tree grades for loblolly and shortleaf pine. Southeastern Forest Expt.

Sta. Tech. Note 69. 13 pp. 1948. Forest Farmer 8(1): 7. 1948.

South. Lumberman 177(2225): 107-109. 1948.

Southern Forest Experiment Station

Interim log grades for southern pine. Southern Forest Expt. Sta. 18 pp. 1953.

Turner, Lewis $\mathrm{M}$.

Factors influencing the rate of growth of pine in Arkansas. Ecology 17(2):

227-240. 1936 .

Turner, Lewis $\mathrm{M}$.

Growth of second-growth pine on the coastal plain soils of Arkansas.

Arkansas Agr. Expt. Sta. Bul. 342. 52 pp. 1937.

Turner, Lewis M.

Some soil characteristics influencing the distribution of forest types and

rate of growth of trees in Arkansas. Jour. Forestry 35(1): 5-11. 1937.

Turner, Lewis $\mathrm{M}$.

Some profile characteristics of the pine-growing soils of the coastal

plain region of Arkansas. Arkansas Agr. Expt. Sta.Bul. 361.52 pp. 1938.

Turner, Lewis M.

Relation of stand density to height growth. Jour. Forestry 41(10): 766. 1943.

U. S. Forest Service

Volume, yield, and stand tables for second-growth southern pines.

U. S. Dept. Agr. Misc. Pub. 50. 202 pp. 1929.

U. S. Forest Service

Volume tables, converting factors, and other' information applicable to commercial timber in the South. U. S. Forest Serv. Region 8, Div. State and Private Forestry. 49 pp. 1951.

Wackerman, A. E.

The management of shortleaf and loblolly pine for sawtimber. Jour.

Forestry 29(1): 3-10. 1931. 
Wahlenberg, W. G.

Methods of forecasting timber growth in irregular stands. U. S. Dept. Agr. Tech. Bul. 796. 56 pp. 1941.

Wahlenberg, W. G.

Forest succession in the southern Piedmont region. Jour. Forestry 47(9): $713-715.1949$.

Wakeley, Philip C.

Artificial reforestation in the southern pine region. U. S. Dept. Agr. Tech. Bul. 492. 114 pp. 1935.

Wakeley, Philip C.

How much forest planting have we to do? South. Lumberman 171(2153):

163-167. 1945.

Watkins, Virgil G.

An analysis of natural reproduction under a two-cut shelterwood system in a shortleaf pine-oak stand in the Duke Forest. Unpublished thesis, Duke Univ. 1946.

Weddell, D. J.

Harvest cuttings in the southern Piedmont region. Jour. Forestry 48(5): $354-356.1950$.

Wheeler, P. R., and Reynolds, R. R.

Forest management pays off in southern Arkansas. Jour. Forestry 50(5): 395-396. 1952.

Wood, O. M.

Early survival of some pine interplantings in southern New Jersey. Jour. Forestry 34(9): 873-878. 1936.

Wood, O. M.

Reproduction of shortleaf pine following mechanical treatment of the seedbed. Jour. Forestry 37(10): 813-814. 1939.

Wyman, Lenthall

Results from sample plots in southern pine experiments. Jour. Forestry 20(7): 780-787. 1922 . 


\title{
ECOLOGY AND PHYSIOLOGY
}

\begin{abstract}
Plant succession - Plant associates - Hardwood invasion of pine stands - Nutritional requirements - Site index factors - Site classification - Comparative tolerance Chemical composition of needles and wood - Effect of mycorrhiza - Normal growth of roots and tops - Drought resistance.
\end{abstract}

Auten, J. T.

Response of shortleaf and pitch pine to soil amendments and fertilizers in newly established nurseries in the central states. Jour. Agr. Res. 70(12): 405-426. June 15, 1945.

Baker, Frederick S.

A revised tolerance table. Jour. Forestry 47(3): 179-181. 1949.

Barrett, Leonard I., and Downs, Albert A.

Hardwood invasion in pine forests of the Piedmont Plateau. Jour. Agr. Res. 67(3): $111-128$. 1943 .

Barton, Lela V.

Hastening the germination of southern pine seeds. Jour. Forestry 26(6): 774-785. 1928.

Becton, W. R.

Effects of varying densities of hardwood cover on growth and survival of shortleaf pine reproduction. Jour. Forestry 34(2): 160-164. 1936.

Billings, William Dwight

The structure and development of old field shortleaf pine stands and certain associated physical properties of the soil. Ecol. Monog. 8(3):437-499.1938.

Boggess, W. R.

Diameter growth of shortleaf pine (Pinus echinata) and white oak (Quercus alba) during a dry season. Univ. Ill. Agr. Expt. Sta. Forestry Note 37, 7 pp. 1953.

Bramble, W. C., and Holst, E. C.

Fungi associated with Dendroctonus frontalis in killing shortleaf pines and their effects on conduction. Phytopathology 30: 881-899. 1940.

Broadfoot, W. M.

Forest planting sites in north Mississippi and west Tennessee. Southern Forest Expt. Sta. Occas. Paper 120. 15 pp. 1951. 
Buell, Murray F., and Cantlon, J. E.

A study of two communities of the New Jersey pine barrens and a comparison of methods. Ecology 31(4): 567-586. 1950.

Butts, Dorothy, and Buckholz, J. T.

Cotyledon numbers in conifers. Ill. State Acad. Sci. Trans. 33(2): 58-62. 1940 .

Byram, G. M., and Doolittle, W. T.

A year of growth for a shortleaf pine. Ecology 31(1): 27-35. 1950.

Cain, S. A., and Cain, L. G.

Size-frequency characteristics of Pinus echinata pollen. Bot. Gaz. 110(1): $325-330$. 1948 .

Caird, Ralph W.

Physiology of pines infested with bark beetles. Bot. Gaz. 96(4): 709-733.

1935.

Chandler, R. F., Jr., Schoen, P. W., and Anderson, D. A.

Relation between soil types and the growth of loblolly pine and shortleaf

pine in east Texas. Jour. Forestry 41(7): 505-506. 1943.

Chapman, Arthur G.

Tolerance of shortleaf pine seedlings for some variations in soluble calcium and $\mathrm{H}$-ion concentration. Plant Physiology 16(2): 313-326. 1941.

Chen, W. -H. W., and Cameron, F. K.

Cellulose content of cotton and Southern woods. Indus. and Engin. Chem. (Indus. Ed.) 34: 224-225. 1942. Forestry Abs. 4(2): 114. 1942.

Chisman, H. H., and Schumacher, F. X.

On the tree-area ratios and certain of its applications. Jour. Forestry 38(4): $311-317.1940$.

Clark, Harry Dale, Jr.

The effect of ground cover on germination and establishment of loblolly and shortleaf pines. Unpublished thesis. Louisiana State Univ. 1948. (Abs.) Jour. Forestry 47(5): 377. 1949.

Clark, Stuart F.

Forest enemy number two. South. Lumberman 175(2201): 182-184. 1947.

Coile, T. S.

Soil reaction and forest types in the Duke Forest. Ecology 14(4): 323-333. 1933. 
Coile, T. S. Relation of site index for shortleaf pine to certain physical properties of the soil. Jour. Forestry 33(8): 726-730. 1935.

Coile, T. S.

The effect of rainfall and temperature on the annual radial growth of pine in the Southern United States. Ecol. Monog. 6(4): 533-562. 1936.

Coile, T. S.

Distribution of forest tree roots in North Carolina Piedmont soils. Jour. Forestry 35(3): 247-257. 1937.

Coile, T. S.

Forest classification: classification of forest sites with special reference to ground vegetation. Jour. Forestry 36(10): 1062-1066. 1938.

Coile, T. S.

Forest soil fertility: influence of stand composition on nitrogen transformation in the surface soil. Soil Sci. Soc. Amer. Proc. 3: 225-229. 1938.

Coile, T. S.

Relation of soil characteristics to site index of loblolly and shortleaf pines in the lower Piedmont region of North Carolina. Duke Univ. School of Forestry Bul. 13. 78 pp. 1948.

Coile, T. S.

Effect of soil in the development of hardwood understories in pine stands of the Piedmont Plateau. Soil Sci. Soc. Amer. Proc. 14: 350-352. 1950.

Coile, T. S.

Soil productivity for southern pines. Part I - Shortleaf and loblolly pines. Forest Farmer 11(7): 10, 11, 13. 1952.

Coile, T. S.

Soil and the growth of forests. Advances in Agronomy 4: 329-398. 1952.

Coile, T. S., and Schumacher, F. X.

Site index of young stands of loblolly and shortleaf pines in the Piedmont

plateau region. Jour. Forestry 51(6): 432-435. 1953.

Coile, T. S., and Schumacher, F. X.

Relation of soil properties to site index of loblolly and shortleaf pines in the Piedmont Region of the Carolinas, Georgia, and Alabama. Jour. Forestry 51(10): 739-744. 1953.

Copeland, O. L., Jr.

Relationship of soils to littleleaf disease in pine. Forest Farmer 8(4): 6 1949. 
Copeland, O. L., Jr.

Some relations between soils and the littleleaf disease of pine. Jour. Forestry 47(7): $566-568$. 1949.

Copeland, O. L., Jr.

Root mortality of shortleaf and loblolly pine in relation to soils and littleleaf disease. Jour. Forestry 50(1): 21-25. 1952.

Corthell, Richard Eldon

A comparison of tree site index with site index estimated from the soil for young shortleaf pine stands. Unpublished thesis, Duke Univ. 1949.

Cruikshank, J. W.

Site index of the major pine forest types in the Southeast. Southeastern

Forest Expt. Sta. Res. Note 50. 1954.

Cummings, William $\mathrm{H}$.

Fertilizer trials for improved establishment of shortleaf pine, white ash, and yellow-poplar plantings on adverse sites. Jour. Forestry 39(11):

942-946. 1941.

Cummings, William $\mathrm{H}$.

Exposure of roots of shortleaf pine stock. Jour. Forestry 40(6): 490-492. 1942 .

\section{Diftler, Nathan}

The invasion of hardwoods in pine stands as related to soil texture on the upland soil types of the lower Piedmont Plateau region of Durham County and its adjacent area. Unpublished thesis, Duke Univ. 1947.

Ferrell, William K.

Effect of environmental conditions on survival and growth of forest tree seedlings under field conditions in the Piedmont region of North Carolina. Ecology 34(4): 667-688. 1953.

Finn, Raymond F.

Foliar nitrogen and growth of certain mixed and pure forest plantings.

Jour. Forestry 51(1): 31-33. 1953.

Garland $\mathrm{H}$.

A microscopic study of coniferous wood in relation to its strength properties.

Reprint from Mo. Bot. Gard. Ann. Rpt. 26(1): 1-95. 1939.

Garren, Kenneth $\mathrm{H}$.

Effects of fire on vegetation of the southeastern United States. Bot. Rev. 9(9): 617-654. 1943 .

Gibbs, J. A., and Ligon, W. S.

The correlation of sites and species in tree planting. Soil Sci. Soc. Amer.

Proc. 6: 413.1941.

Grano, C. X.

Is litter a barrier to the initial establishment of shortleaf and loblolly pine reproduction? Jour. Forestry 47(7): 544-548. 1949. 
Hahn, Vernon W.

The effect of soil and air temperatures on the resumption of growth by tree seedlings in the spring. Unpublished thesis, Duke Univ. 1942.

Hall, William L.

Is pine coming or going in south Arkansas? Jour. Forestry 43(9): 634-637. 1945.

Hepting, George $\mathrm{H}$.

Reserve food storage in shortleaf pine in relation to littleleaf disease.

Phytopathology 35(2): 106-119. 1945.

Hobbs, C. H.

Studies on mineral deficiency in pine. Plant Physiol. 19(4): 590-602. 1944.

Hobbs, James E.

A study of the relationship between soil texture and establishment of pine reproduction, as affecting silvicultural practices on upland Piedmont soils in Durham County and vicinity in North Carolina. Unpublished thesis, Duke Univ. 1947.

Huberman, M. A.

Normal growth and development of southern pine seedlings in the nursery.

Ecology 21(3): 323-334. 1940.

Huckenpahler, B. J.

Amount and distribution of moisture in a living shortleaf pine. Jour.

Forestry 34(4): 399-401. 1936.

Hunt, Francis M.

Effects of flooded soil on growth of pine seedlings. Plant Physiol. 26(2): 363-368. 1951 .

Jackson, L. W. R.

Effect of littleleaf disease on growth of shortleaf pine. Jour. Forestry 49(11):

$778-779.1951$.

Jackson, L. W. R.

Radial growth of forest trees in the Georgia Piedmont. Ecology 33(3):

336-341. 1952.

Jemison, George M.

Effect of litter removal on diameter growth of shortleaf pine. Jour. Forestry 41(3): 213-214. 1943.

Jemison, George M.

Effect of single fires on the diameter growth of shortleaf pine in the southern

Appalachians. Jour. Forestry 41(8): 574-576. 1943.

Johnston, John P.

Height-growth periods of oak and pine reproduction in the Missouri Ozarks.

Jour. Forestry 39(1): 67-68. 1941. 
Kittredge, J.

Deterioration of site quality by erosion. Jour. Forestry 50(7): 554-556. 1952.

Korstian, Clarence F., and Coile, T. S.

Plant competition in forest stands. Duke Univ. School of Forestry Bul. 3. 125 pp. 1938.

Kozlowski, Theodore Thomas

The transpiration rates of some forest tree species during the dormant season. Unpublished thesis, Duke Univ. 1941.

Kozlowski, Theodore Thomas

Light and water in relation to growth and competition of Piedmont forest

tree species. Ecol. Monog. 19(3): 207-231. 1949.

Kramer, Paul J.

Amount and duration of growth of various species of tree seedlings.

Plant Physiol. 18(2): 239-251. 1943.

Kramer, Paul J., and Wilbur, Karl M.

Absorption of radioactive phosphorus by mycorrhizal roots of pine.

Science $110(2844): 8-9.1949$.

Kramer, Paul J., Oosting, Henry J., and Korstian, Clarence F.

Survival of pine and hardwood seedlings in forest and open. Ecology 33(3):

$427-430.1952$.

Lange, Keith D.

Effects of clearcutting understory hardwoods on the growth of a shortleaf-

Virginia pine stand. Jour. Forestry 49(3): 176-178. 1951.

Liming, Franklin G.

Response of planted shortleaf pine to overhead release. Central States

Forest Expt. Sta. Tech. Paper 105. 20 pp. 1946.

Liming, Franklin G., and Seizert, B. F.

Relative height growth of planted shortleaf pine and cut-back and uncut

hardwood reproduction after release. Jour. Forestry 41(3): 214-216. 1943.

Limstrom, G. A., and Deitschman, G. H.

Early response to thinning of shortleaf pine in Indiana. Central States

Forest Expt. Sta. Note 82. 1953.

Little, S., and Moore, E. B.

The ecological role of prescribed burns in the pine-oak forests of southern

New Jersey. Ecology 30(2): 223-233. 1949. 
Lynch, D. W., et al.

Influence of nursery fungicide-fertilizer treatments on survival and growth

in a southern pine plantation. Jour. Forestry 41(6): 411-413. 1943.

Mann, William F., Jr.

Releasing loblolly and shortleaf reproduction. Forest Farmer 8(8): 3, 10 . 1949.

Marshall, Robert

An experimental study of the water relations of seedling conifers with special reference to wilting. Ecol. Monog. 1(1): 39-98. 1931.

Mattoon, Wilbur R.

The sprouting of shortleaf pine in the Arkansas National Forest. Forestry Quarterly 6(2): 158-159. 1908.

Mattoon, Wilbur R.

Life history of shortleaf pine. U. S. Dept. Agr. Bul. 244. 46 pp. 1915.

Mattoon, Wilbur R.

Shortieaf and loblolly pine litter and humus a valuable fertilizer. U. S.

Dept. Agr. Forest Worker 5(2): 14-15. 1929.

McDermott, R. E., and Burns, P. Y.

Effect of fertilizer on planted pine. Jour. Forestry 49(9): 633. 1951.

McQuilkin, W. E.

Root development of pitch pine, with some comparative observations on shortleaf pine. Jour. Agr. Res. 51(11): 983-1016. 1935.

McQuilkin, W. E.

The natural establishment of pine in abandoned fields in the Piedmont Plateau region. Ecology 21(2): 135-147. 1940. Appalachian Forest Expt. Sta. Tech. Note 37. 3 pp. 1939 .

Miller, Frank J.

The influence of mycorrhizae on the growth of shortleaf pine seedlings. Jour. Forestry 36(5): 526-527. 1938.

Miller, P. R.

Treatment of shortleaf pine and loblolly pine seed with fungicidal dusts. Agr. Chemicals 6(8): 47, 49. Aug. 1951.

Minckler, Leon S.

Plantation survival as related to soil type, aspect, and growing season. Jour. Forestry 39(1): 26-29. 1941.

Minckler, Leon S.

The right tree in the right place. Jour. Forestry 39:8): 685-688. 1941. 
Minckler, Leon S.

Effect of rainfall and site factors on the growth and survival of young forest plantations. Jour. Forestry 41(11): 829-833. 1943.

Minckler, Leon S.

Old field reforestation in the great Appalachian valley as related to some ecological factors. Ecol. Monog. 16(1): 87-108. 1946.

Minckler, Leon S.

Poor oak sites may grow good pine. Central States Forest Expt. Sta.

Tech. Paper 134. 6 pp. 1953.

Minckler, Leon S., and Deitschman, G. H.

Success of planted pines varies with species and site. Central States

Forest Expt. Sta. Note 76. 2 pp. 1953.

Moore, E. B.

Seedling-sprout growth of shortleaf and pitch pine in New Jersey. Jour.

Forestry 34(9): 879-882. 1936.

Nelson, M. L.

Polyembryony in seeds of southern pines. Jour. Forestry 39(11): 959-960. 1941.

Nelson, T. C.

Honeysuckle is a serious problem. Forest Farmer 12(11): 14-16. 1953.

Oosting, Henry J.

An ecological analysis of the plant communities of Piedmont North Carolina. Amer. Midland Nat. 28(1): 1-126. 1942.

Oosting, Henry J.

Comparative effect of surface and crown fire on the composition of a

loblolly pine community. Ecology 25: 61-69. Jan. 1944.

Oosting, Henry J., and Kramer, Paul J.

Water and light in relation to pine reproduction. Ecology 27(1): 47-53.1946.

Ostrom, Carl E.

Effect of plant-growth regulators on shoot development and field survival of

forest-tree seedlings. Bot. Gaz. 107(2): 139-183. 1945.

Perry, George S.

Calcium--the key to forest productivity. Jour. Forestry 26(6): 767-773. 1928.

Perry, George S.

Recovery of shortleaf and Virginia pines after forest fire. Tenn. Valley

Authority Dept. For. Relations Tech. Note 3. 2 pp. 1942.

Pessin, L. J.

Mycorrhiza of southern pines. Ecology 9(1): 28-33. 1928. 


\section{Ecology and Physiology}

Reed, John F.

Root and shoot growth of shortleaf and loblolly pines in relation to certain environmental conditions. Duke Univ. School of Forestry Bul. 4. 52 pp. 1939.

Righter, F. I.

Early flower production among the pines. Jour. Forestry 37(12): 935-938. 1939 .

Roth, Elmer R., Toole, E. R., and Hepting, G. H.

Nutritional aspects of the littleleaf disease of pine. Jour. Forestry 46(8): 578-587. 1948.

Routein, J. B., and Dawson, R. F.

Some interrelationships of growth, salt absorption, respiration, and mycorrhizal development in Pinus echinata Mill. Amer. Jour. Bot. 30(6): 440-451. 1943.

Schopmeyer, C. S.

Transpiration and physico-chemical properties of leaves as related to drought resistance in loblolly pine and shortleaf pine. Plant Physiol. 14(3): 447-462. 1939 .

Smith, Lloyd F.

Early results of a liberation cutting in a pine-hardwood stand in Northern Louisiana. Jour. Forestry 45(4): 278-282. 1947.

St. George, R. A., and Huckenpahler, B. J.

Distribution of moisture in pines. Jour. Forestry 32(8): 885. 1934.

Stoehr, Henry A.

Estimation of site index for pine in the lower Piedmont Plateau on the basis of certain soil characteristics. Unpublished thesis, Duke Univ. 1946.

Stone, Earl L., Jr., and Stone, Margaret $\mathrm{H}_{\text {. }}$

Dormant buds in certain species of pinus. Amer. Jour. Bot. 30(5): 346-351 1943.

Turner, Lewis M.

The status of the southern shortleaf pine in the northwestern Ozark region.

Transactions of the Illinois Academy of Science 28(2): 115-116. 1935.

Turner, Lewis M.

Catastrophies and pure stands of southern shortleaf pine. Ecology 16(2):

213-215. 1935.

Turner, Lewis M.

Factors influencing the rate of growth of pine in Arkansas. Ecology 17(2):

227-240. 1936. 
Turner, Lewis M.

A comparison of roots of southern shortleaf pine in three soils. Ecology 17(4): $649-658.1936$.

Turner, Lewis M.

Root growth of seedlings of Pinus echinata and Pinus taeda. Jour. Agr.

Res. 53(2): 145-149. 1936.

Turner, Lewis M.

Some soil characteristics influencing the distribution of forest types and rate of growth of trees in Arkansas. Jour. Forestry 35(1): 5-11. 1937.

Turner, Lewis $M$.

Some profile characteristics of the pine-growing soils of the Coastal Plain region of Arkansas. Arkansas Agr. Expt. Sta. Bul. 361. 52 pp. 1938.

Wahlenberg, W. G.

Forest succession in the southern Piedmont region. Jour. Forestry 47(9): 713-715. 1949 .

Wakeley, Philip C.

Where and how can the pines be reproduced. South. Lumberman 169(2129): 140-145. 1944.

Wakeley, Philip C.

Physiological grades of southern pine nursery stock. Soc. Amer. Foresters Proc. 1948: 311-322. 1949.

Weddell, D. J.

Viable seed from nine-year-old southern pine. Jour. Forestry 33(11): 902. 1935.

Wenger, K. F.

Effect of moisture supply and soil texture on the growth of sweetgum and pine seedlings. Jour. Forestry 50(11): 862-864. 1952.

Wherry, Edgar T.

Soil acidity preferences of some eastern conifers. Jour. Forestry 20(5): 488-496. 1922 .

Wilde, S. A., and Voigt, G. K.

Absorption-transpiration quotient of nursery stock. Jour. Forestry 47(8): 643-645. 1949.

Williston, H. L.

Height growth of pine seedlings. Jour. Forestry 49(3): 205. 1951.

Wilson, Charles C.

The response of two species of pine to various levels of nutrient zinc.

Science 117(3035): 231-233. 1953. 


\section{REGENERATION}

Seed handling - Seed storage - Nursery practice Mycorrhiza on seedlings - Growth of seedlings Planting outside natural range - Planting for erosion control - Direct seeding - Natural regeneration - Seed tree selection - Seedbed preparation - Seed production.

Allen, John C.

Pine planting tests in the Copper Basin. Jour. Tenn. Acad. Sci. 25(3): 199-216. 1950.

Attridge, J. Milton, and Liming, Franklin G.

Establishment of shortleaf pine in the Missouri Ozarks following seedbed preparations and release. Central States Forest Expt. Sta. Tech. Note 10. 1940.

Auten, J. T.

Response of shortleaf and pitch pine to soil amendments and fertilizers in newly established nurseries in the central states. Jour. Agr. Res. 70(12): 405-426. June 15, 1945.

Barrett, Leonard I.

Observations on requirements for restocking cutover loblolly and shortleaf pine stands. Appalachian Forest Expt. Sta. Tech. Note 42. 9 pp. 1940.

Barrett, Leonard I.

Requirements for restocking cutover loblolly and shortleaf pine stands. South. Lumberman 161(2033): 200-202. 1940.

Barton, Lela V.

Hastening the germination of southern pine seeds. Jour. Forestry 26(6): $774-785.1928$.

Barton, Lela V.

Storage of some coniferous seeds. Boyce Thompson Inst. Contrib. 7(4): 379-404. 1935.

Becton, W. R.

Effects of varying densities of hardwood cover on growth and survival of shortleaf pine reproduction. Jour. Forestry 34(2): 160-164. 1936.

Boggess, W. R.

Fall planting studies with pine in southern Illinois. Univ. of Ill. Agr. Expt. Station Forestry Note 25. 6 pp. 1951.

Brinkman, K. A., and Swarthout, P. A.

Natural reproduction of pines in east-central Alabama. Ala. Agr. Expt. Sta. Cir. 86. 12 pp. 1942.

Broadfoot, W. M.

Forest planting sites in north Mississippi and west Tennessee. Southern

Forest Expt. Sta. Occas. Paper 120. 15 pp. 1951. 
Chapman, Arthur G.

Observations on the nursery development of shortleaf pine seedlings.

Central States Forest Expt. Sta. Note 22. 5 pp. 1935.

Chapman, Arthur G.

Tolerance of shortleaf pine seedlings for some variations in soluble calcium and H-ion concentration. Plant Physiol. 16(2): 313-326. 1941.

Chapman, Arthur G.

Classes of shortleaf pine nursery stock for planting in the Missouri Ozarks. Jour. Forestry 42(11): 818-826. 1944.

Chapman, Arthur G.

Survival and growth of various grades of shortleaf pine planting stock.

Iowa State College Jour. Science 22(4): 323-331. 1948.

Clark, Harry Dale, Jr.

The effect of ground cover on germination and establishment of loblolly and shortleaf pines. Unpublished thesis, Louisiana State Univ. 1948. (Abs.) Jour. Forestry 47(5): 377. 1949.

Cossitt, F. M.

Mineral spirits as a selective herbicide in southern pine seed-bed. South . Lumberman 175(2201): 203-204. 1947.

Cummings, William $\mathrm{H}$.

Fertilizer trials for improved establishment of shortleaf pine, white ash, and yellowpoplar plantings on adverse sites. Jour. Forestry 39(11): 942-946. 1941.

Cummings, William $\mathrm{H}$.

Exposure of roots of shortleaf pine stock. Jour. Forestry 40(6): 490-492. 1942.

Dingle, R. W.

Survival and growth of forest plantations in Missouri. Jour. Forestry 50(11): 845-849. 1952.

Downs, Albert A.

Choosing pine seed trees. Jour. Forestry 45(8): 593-594. 1947.

Ferrell, William K.

Effect of environmental conditions on survival and growth of forest tree seedlings under field conditions in the Piedmont region of North Carolina. Ecology 34(4): 667-688. 1953.

Finn, Raymond F.

Foliar nitrogen and growth of certain mixed and pure forest plantings. Jour. Forestry 51(1): 31-33. 1952.

Garin, G. I.

Establishment of loblolly and shortleaf pine reproduction on a clear cut strip. Jour. of the Ala. Acad. Sci. 21/22: 20-23. 1952. 
Gibbs, J. A.

Growth of tree plantings for erosion control in the southeastern region. Iowa State Col. Jour. Sci. 22(4): 371-386. 1948.

Gibbs, J. A.

Tree plantings control erosion and produce wood. Forest Farmer 8(2):

5. 1948.

Gibbs, J. A., and Ligon, W. S.

The correlation of sites and species in tree planting. Soil. Sci. Soc.

Amer. Proc. 6: 413. 1941.

Grano, C. X.

Is litter a barrier to the initial establishment of shortleaf and loblolly

pine reproduction? Jour. Forestry 47(7): 544-548. 1949.

Grano, C. X.

Re-establishment of shortleaf-loblolly pine under four cutting methods.

Jour. Forestry 52(2): 132-133. 1954.

Hahn, Vernon W.

The effect of soil and air temperatures on the resumption of growth of tree seedlings in the spring. Unpublished thesis, Duke Univ. 1942.

Hamilton, S. W.

Ratios of clean and rough seed. Jour. Forestry 41(1): 63-64. 1943.

Hobbs, C. H.

Studies on mineral deficiency in pine. Plant Physiol. 19(4): 590-602. 1944.

Hobbs, James E.

A study of the relationship between soil texture and establishment of pine reproduction, as affecting silvicultural practices on upland Piedmont soils in Durham County and vicinity in North Carolina. Unpublished thesis, Duke Univ. 1947.

Huberman, M. A.

Studies in raising southern pine nursery seedlings. Jour. Forestry 38(4): $341-345.1940$.

Huckenpahler, B. J.

Which is best? A study of loblolly vs. shortleaf. South Lumber Jour. 53(3):

19, 108. 1949 .

Huckenpahler, B. J.

Development of nineteen-year-old southern pine plantations in Tennessee. Jour. Forestry 48(10): 722-723. 1950.

Hunt, Francis M.

Effects of flooded soil on growth of pine seedlings. Plant Physiol. 26(2): 363-368. 1951. 
Jackson, L. W. R.

"Needle curl" of shortleaf pine seedlings. Phytopathology 38: 1029-1029. 1948.

Jackson, L. W. R.

Influence of littleleaf on quality of shortleaf pine seed. Phytopathology 42(1): 57-58. 1952 .

Johnston, H. R., and Eaton, C. B.

Tests with various chemicals for the control of white grubs in forest nurseries of the Carolinas. Jour. Forestry 40(9): 712-721. 1942.

Johnston, John P.

Height-growth periods of oak and pine reproduction in the Missouri Ozarks. Jour. Forestry 39(1): 67-68. 1941.

Kramer, Paul J.

Amount and duration of growth of various species of tree seedlings. Plant Physiol. 18(2): 239-251. 1943.

Kramer, Paul J., Oosting, Henry J., and Korstian, Clarence F.

Survival of pine and hardwood seedlings in forest and open. Ecology 33(3): $427-430.1952$.

Lamb, Howard

Rust canker diseases of southern pine. Southern Forest Expt. Sta. Occas. Paper 72. 7 pp. 1937.

Liming, Franklin G.

Natural regeneration of shortleaf pine in the Missouri Ozarks. Jour.

Forestry 43(5): 339-345. 1945.

Liming, Franklin G., and Seizert, B. F.

Relative height growth of planted shortleaf pine and cut-back and uncut

hardwood reproduction after release. Jour. Forestry 41(3): 214-216. 1943.

Little, S.

Seedfall of shortleaf pine. Allegheny Forest Expt. Sta. Tech. Note 27. 1940.

Little, S., and Moore, E. B.

Effect of prescribed burns and shelterwood cutting on reproduction of shortleaf and pitch pine. Northeastern Forest Expt. Sta. Paper 35. 11 pp. 1950.

Lynch, D. W., et al.

Influence of nursery fungicide-fertilizer treatments on survival and growth in a southern pine plantation. Jour. Forestry 41(6): 411-413. 1943. 
Mann, William F., Jr.

Releasing loblolly and shortleaf reproduction. Forest Farmer 8(8): 3, 10. 1949.

Mann, William F., Jr.

Profits from release of loblolly and shortleaf pine seedlings. Jour. Forestry 49(4): 250-253. 1951 .

Marshall, Robert

An experimental study of the water relations of seedling conifers with

special reference to wilting. Ecol. Monog. 1(1): 39-98. 1931

McDermott, R. E。, and Burns, P. Y.

Effect of fertilizer on planted pine. Jour. Forestry 49(9): 633. 1951.

McKinnon, A。 D.

Development of southern pines in Auckland conservancy. New Zealand

Jour. Forestry 5(2): 127-132. 1945. Forestry Abs. 8(2): 226. 1946.

McLintock, Thomas F.

Stratification as a means of improving results of direct seeding of pines.

Jour. Forestry 40(9): 724-728. 1942.

McQuilkin, W. E.

Natural establishment of pine in abandoned fields in the Piedmont Plateau region. Ecology 21(2): 135-147. 1940.

McQuilkin, W. E.

Note on direct seeding in the southeastern Piedmont region. Jour. Forestry 38(9): $734-735$. 1940 .

McQuilkin, W. E.

Tests of direct seeding with pines in the Piedmont region. Jour. Agr. Res. 73(4): 113-136. 1946 .

Meginnis, H. G.

Using soil-binding plants to reclaim gullies in the South. U. S. Dept. Agr.

Farmers' Bul. 1697. 18 pp. 1933.

Meginnis, H. G.

Tree planting to reclaim gullied lands in the South. Jour. Forestry 31(6):

649-656. 1933.

Meginnis, H. G.

Soil-collecting trenches as substitutes for temporary check dams in re-

foresting gullies. Jour. Forestry 37(10): 764-769. 1939.

Miller, Frank J.

The influence of mycorrhizae on the growth of shortleaf pine seedlings.

Jour. Forestry 36(5): 526-527. 1938. 
Miller, P. R.

Treatment of shortleaf pine and loblolly pine seed with fungicidal dusts.

Agr. Chemicals 6(8): 47, 49. Aug. 1951.

Minckler, Leon S.

Plantation survival as related to soil type, aspect, and growing season.

Jour. Forestry 39(1): 26-29. 1941.

Minckler, Leon S.

The right tree in the right place. Jour. Forestry 39(8): 685-688. 1941.

Minckler, Leon S.

Early results from a reforestation pilot plant. Jour. Forestry 42(8): 586-590. 1944.

Minckler, Leon S.

Old field reforestation in the great Appalachian valley as related to some ecological factors. Ecol. Monog. 16(1): 87-108. 1946.

Minckler, Leon S.

Planted pines on clay pan soils of southern Illinois. Central States Forest Expt. Sta. Note 44.1948.

Minckler, Leon S.

Effect of seed source on height growth of pine seedlings. Jour. Forestry 48(6): 430-431. 1950 .

Minckler, Leon S.

Southern pines from different geographic sources show different responses

to low temperatures. Jour. Forestry 49(12): 915-916. 1951.

Minckler, Leon S.

Fall planting of pine on upland soils of southern Illinois. Central States

Forest Expt. Sta. Tech. Paper 118. 11 pp. 1951.

Minckler, Leon S., and Chapman, Arthur G.

Direct seeding of pines in the central hardwoods region. Central States

Forest Expt. Sta. Tech. Paper 140. 1954.

Minckler, Leon S., and Deitschman, G. H.

Success of planted pines varies with species and site. Central States

Forest Expt. Sta. Note 76. 1953.

Minckler, Leon S., and Downs, Albert A.

Machine and hand direct seeding of pine and cedar in the Piedmont.

Southeastern Forest Expt. Sta. Tech. Note 67. 10 pp. 1946.

Moore, E. B.

Seedling-sprout growth of shortleaf and pitch pine in New Jersey. Jour.

Forestry 34(9): 879-882. 1936.

Nelson, M. L.

Preliminary investigations on dry, cold storage of southern pine seed.

Southern Forest Expt. Sta. Occas. Paper 78. 19 pp. 1938. 
Nelson, M. L.

Successful storage of southern pine seed for seven years. Jour. Forestry 38(5): 443-444. 1940.

Nelson, M. L.

Polyembryony in seeds of southern pines. Jour. Forestry 39(11): 959-960. 1941.

Nelson, T. C.

Honeysuckle is a serious problem. Forest Farmer 12(11): 14-16. 1953.

Oosting, Henry J., and Kramer, Paul J.

Water and light in relation to pine reproduction. Ecology 27(1): 47-53. 1946.

Ostrom, Carl E.

Effects of plant-growth regulators on shoot development and field survival

of forest-tree seedlings. Bot. Gaz. 107(2): 139-183. 1945.

Perry, George S., and Coover, C. A.

Seed source and quality. Jour. Forestry 31(1): 19-25. 1933.

Reynolds, R. R.

Natural reproduction of shortleaf and loblolly pine over long distances.

U. S. Forest Serv. Service Bul. 17(17): 3. 1933.

Routein, J. B., and Dawson, R. F.

Some interrelationships of growth, salt absorption, respiration, and

mycorrhizal development in Pinus echinata Mill. Amer. Jour. Bot. 30(6):

$440-451.1943$.

Schavilje, Joseph P.

Reclaiming Illinois strip mined coal lands with trees. Jour. Forestry 39(8): 714-719. 1941 .

Schopmeyer, C. S.

Transpiration and physico-chemical properties of leaves as related to

drought resistance in loblolly pine and shortleaf pine. Plant Physiol. 14(3): $447-462$. 1939 .

Siggins, Howard W.

Distribution and rate of fall of conifer seeds. Jour. Agr. Res. 47(2):

$119-128.1933$.

Turner, Lewis M.

Root growth of seedlings of Pinus echinata and Pinus taeda. Jour. Agr. Res. 53(2): 145-149. 1936.

Wakeley, Philip C.

Seed yield data for southern pines. Jour. Forestry 28(3): 391-394. 1930.

Wakeley, Philip C.

Some observations on southern pine seed. Jour. Forestry 29(8): 1150-1164. 1931. 
Wakeley, Philip C.

Artificial reforestation in the southern pine region. U. S. Dept. Agr. Tech. Bul. 492. 114 pp. 1935.

Wakeley, Philip C.

Collecting, extracting, and marketing southern pine seed. Southern

Forest Expt. Sta. Occas. Paper 51. 10 pp. 1935.

Wakeley, Philip C.

Harvesting and selling seed of southern pines. U. S. Dept. Agr. Leaflet 156. 8 pp. 1938 .

Wakeley, Philip C.

Estimate of the cone crop of southern pines. Southern Forest Expt. Sta.

(10 mimeographed reports, 1931-1940).

Wakeley, Philip C.

Where and how can the pines be reproduced. South. Lumberman 169

(2129): 140-145. 1944.

Wakeley, Philip C.

How much forest planting have we to do. South. Lumberman 171(2153):

163-167. 1945.

Wakeley, Philip C.

Collecting southern pine seed. Forest Farmer 7(12): 1, 7. 1948.

Wakeley, Philip C.

Physiological grades of southern pine nursery stock. Soc. Amer.

Foresters Proc. 1948: 311-322. 1949.

Wakeley, Philip C.

Planting the southern pines. Forest Farmer 11(2): 4-5. 1951.

Wakeley, Philip C.

Planting the southern pines. U. S. Dept. Agr. Monograph 18. 233 pp. 1954.

Wakeley, Philip C.

Storing southern pine seed. Southern Forest Expt. Sta. Occas. Paper 123. 13 pp. 1951.

Wakeley, Philip C.

How seed source and seedling stock affect reforestation. Forest Farmer 12(2): 16,28 . 1952 .

Watkins, Virgil G.

An analysis of natural reproduction under a two-cut shelterwood system in a shortleaf pine-oak stand in the Duke Forest. Unpublished thesis, Duke Univ. 1946. 
Weddell, D. J.

Viable seed from nine-year-old southern pine. Jour. Forestry 33(11): 902. 1935.

Weddell, D. J.

Harvest cuttings in the southern Piedmont region. Jour. Forestry 48(5): $354-356.1950$.

Wenger, K. F。

Effect of moisture supply and soil texture on the growth of sweetgum and pine seedlings. Jour. Forestry 50(11): 862-864. 1952.

Wilde, S. A., and Voigt, G. K.

Absorption - transpiration quotient of nursery stock. Jour. Forestry 47(8): $643-645$. 1949 .

Williston, H. L.

Height growth of pine seedlings. Jour. Forestry 49(3): 205. 1951.

Wood, O. M.

Early survival of some pine interplantings in southern New Jersey. Jour. Forestry 34(9): 873-878. 1936.

Wood, O. M.

Reproduction of shortleaf pine following mechanical treatment of the seedbed. Jour. Forestry 37(10): 813-814. 1939. 


\section{UTILIZATION}

Characteristics and properties of wood - Uses Identification of wood - Pulp and paper manufacture Effect of fungi on wood and wood products -

Preservative treatments - Seasoning of wood.

Anon.

Commercial uses of shortleaf pine. Amer. Forests 22(273): 517-520. 1916.

Anon.

Long and short leaf pine and anti-steam process; soda treatment does not affect its strength or hardness. Lumber Trade Jour. 59(10): 15-17. 1911.

Ashe, W. W.

The use of cut-over shortleaf pine lands. Amer. Lum. (1872): 43-44.1911.

Berkeley, E. E.

Certain physical and structural properties of three species of southern yellow pine correlated with the compression strength of their wood. Annals of the Missouri Botanical Garden 21(2): 241-338. 1934.

Betts, H. S.

Properties and uses of the southern pines. U. S. Forest Serv. Cir. 164. 30 pp. 1909.

Betts, H. S.

The seasoning of wood. U. S. Dept. Agr. Bul. 552. 28 pp. 1917.

Bray, Mark W.

Evaluating of shortleaf pine for pulp production. Paper Trade Journal 99(5): $38-41$. 1934.

Browne, F. L.

Durability of paint on longleaf and shortleaf pine. South. Lumberman 146(1844): 20-2.2. 1933.

Buckman, Stanley

What is the relationship between durability and specific gravity of wood? Jour. Forestry 32(7): 725-728. 1934.

Bull, Henry

Pulpwood yields from experimental thinnings in old field stands of loblolly and shortleaf pines. Southern Forest Expt. Sta. Occas. Paper 57. 9 pp. 1936.

Chapman, A. Dale, and Scheffer, Theodore C.

Effect of blue stain on specific gravity and strength of southern pine.

Jour. Agr. Res. 61(2): 125-133. 1940. 
Chen, W. - H. W., and Cameron, F. K.

Cellulose content of cotton and southern woods. Indus. and Engin. Chem. (Indus. Ed.) 34:224-225. 1942. Forestry Abs. 4(2): 114. 1942.

Chidester, G. H., McGovern, J. M., and McNaughton, C. C.

Comparison of sulfite pulps from fast growth loblolly, shortleaf, longleaf, and slash pines. Paper Trade Jour. 106(4): 36-39. July 28, 1938.

Cook, Richard C.

The inspection of shortleaf pine poles and a study of the possible success-

ful treatment of rejected poles. Unpublished thesis, Duke Univ. 1949.

Curran, C. E.

Relation of growth characteristics of southern pine to its use in pulping. Jour. Forestry 36(6): 576-581. 1938. U. S. Forest Prod. Lab. R 1168. 11 pp. 1938.

Davidson, Ross W.

Fungi causing stain in logs and lumber in the southern states, including

five new species. Jour. Agr. Res. 50(10): 789-807. 1935.

Davis, E. M.

Shortleaf pine, the lumber-making qualities of second-growth and of virgin-growth timber. South. Lumberman 137(1770): 309-310, 312. 1929.

Davis, E. M.

The defects and some other characteristics of virgin-growth and of secondgrowth commercial shortleaf pine lumber. Jour. Forestry 29(1): 54-63. 1931.

Demmon, E. L.

Rate of formation of heartwood in southern pines. Jour. Forestry 34(8): $775-776.1936$.

Downey, E. J.

Open tank creosote treatment of shortleaf and loblolly pine poles. Jour. Forestry 35(4): 349-352. 1937.

Fernow, B. E.

Southern pine-mechanical and physical properties. U. S. Dept. Agr. Div. Forestry Cir. 12. 12 pp. 1896.

Forbes, R. D.

Timber growing and logging and turpentining practices in the southern pine region. U. S. Dept. Agr. Tech. Bul. 204. 115 pp. 1930.

Forest Products Laboratory

Wood handbook. U. S. Dept. Agr. Forest Serv. 326 pp. Rev. 1940.

Forest Products Laboratory

Strength of southern pine and Douglas-fir compared. U. S. Forest Serv. Forest Prod. Lab. Tech. Note 119. Rev. 1952. 
Freas. A. D.

Laminated southern pine. South. Lumberman 187(2345): 168-169. 1953.

Garland, H.

A microscopic study of coniferous wood in relation to its strength

properties. Reprinted from Mo. Bot. Gard. Ann. Rpt. 26(1): 1-95. 1939.

Grabow, Rudolph H.

Suitability of various American woods for pulp and paper making. Jour.

Forestry 21(5): 462-474. 1923.

Gregory, G. R., and Person, H. L.

Pine log grades and lumber recovery. South. Lumberman 173(2177):

168-169. 1946.

Haines, W. H. B.

86 percent of tops and 54 percent of slabs and edgings unused in central

Piedmont of South Carolina. Southeastern Forest Expt. Sta. Res. Note 35. 1953.

Haines, W. H. B.

62 percent of pine lumber is cut from 10-inch or smaller logs in the central Piedmont of South Carolina. Southeastern Forest Expt. Sta. Res. Note 36. 1953.

Hepting, George H.

Blue stain development in peeled shortleaf and loblolly pine pulpwood.

Paper Indus. 17. 402-404. 1935.

Hepting, George H.

Decay and staining of southern pine pulpwood. Paper Indus. and Paper

World 27(3): 379-382. 1945.

Kellogg, L. F., and Kuenzel, J. G.

Lumber grade recovery from shortleaf pine and mixed oak in northern

Arkansas. Jour. Forestry 43(1): 10-15. 1945.

Koehler, Arthur

Guidebook for the identification of woods used for ties and timbers. U. S.

Dept. Agr., Forest Serv. Forest Products Lab., Madison, Wis. Misc。

Pub. R. L. 1. 1917.

Koehler, Arthur

Rapid growth hazards usefulness of southern pine. Jour. Forestry 36(2):

153-158. 1938.

Kurth, E. F.

Distribution and nature of extractives in longleaf and shortleaf pine.

Indus. and Engin. Chem. 25(2): 192-195. 1933. 
Lindgren, Ralph M.

Temperature, moisture, and penetration studies of wood-staining

Ceratostomellae in relation to their control. U. S. Dept. Agr. Tech.

Bul. 807. 35 pp. 1942 .

Lindgren, Ralph M.

Deterioration of southern pine pulpwood during storage. Forest Products

Res. Soc. Preprint 161. 12 pp. 1951.

Lindgren, Ralph M., and Scheffer, Theodore C.

Effect of blue stain on the penetration of liquids into air-dry southern

pine wood. Amer. Wood Preservers' Assoc. Proc. 35: 325-336. 1939.

MacNaughton, W. G.

Ground wood and sulphite pulp from southern pine. Paper Mill and Wood

Pulp News 58(29): 9, 11, 13-15. 1935.

Markwardt, L. J.

Comparative strength properties of woods grown in the United States.

U. S. Dept. Agr. Tech. Bul. 158. 39 pp. 1930.

Markwardt, L. J., and Wilson, T. R. C.

Strength and related properties of woods grown in the United States.

U. S. Dept. Agr. Tech. Bul. 479. 99 pp. 1935.

Mathewson, J. S.

The air seasoning of wood. U. S. Dept. Agr. Tech. Bul. 174. 56 pp. 1930.

Mattoon, Wilbur R.

Pruning southern pine. U. S. Dept. Agr. Farmers Bulletin 1892. 34 pp. 1942.

McClay, T. A.

Lumber grade yields in the loblolly-shortleaf pine type by the southern

pine log grades. Southeastern Forest Expt. Sta. Paper 37.12 pp. 1954.

Morbeck, George C.

Logging shortleaf pine in Arkansas. Ames Forester 3: 92-118. 1915.

Myer, J. E.

Ray volumes of the commercial woods of the United States and their

significance. Jour. Forestry 20(4): 337-351. 1922.

Newlin, J. A., and Wilson, T. R. C.

Mechanical properties of woods grown in the United States. U. S. Dept. Agr. Bul. 556. 47 pp. 1917.

Newlin, J. A., and Wilson, T. R. C.

The relation of the shrinkage and strength properties of wood to its

specific gravity. U. S. Dept. Agr. Bul. 676. 35 pp. 1919. 
Paul, Benson, H.

The application of silviculture in controlling the specific gravity of wood.

U. S. Dept. Agr. Tech. Bul. 168. 20 pp. 1930.

Paul, Benson $\mathrm{H}$.

Mixed stands produce pine lumber of higher grade. South. Lumber Jour. 37(4): 26. 1933.

Paul, Benson $\mathrm{H}$.

Knots in second growth pine and the desirability of pruning. U. S. Dept.

Agr. Misc. Pub. 307. 35 pp. 1938.

Paul, Benson $\mathrm{H}$.

Reducing bowing and crooking of lumber cut from second-growth southern

yellow pine. South. Lumberman 156(1962): 48-50. 1938.

Paul, Benson $\mathrm{H}$.

Variation in the specific gravity of the springwood and summerwood of four species of southern pines. Jour. Forestry 37(6): 478-482. 1939.

Reynolds, R. R.

Pulpwood production studies in shortleaf-loblolly pine stands. Southern

Forest Expt. Sta. Occas. Paper 71. 5 pp. 1937.

Reynolds, R. R.

Studies of pulpwood production in shortleaf-loblolly pine stands. Paper

Trade Jour. 106(17): 64-65. 1938.

Reynolds, R. R.

Pulpwood production costs in southeast Arkansas, 1950. Southern Forest

Expt. Sta. Occas. Paper 121. 17 pp. 1951.

Reynolds, R. R.

Pulpwood production costs and methods in southeastern Arkansas. South.

Pulp and Paper Manufacturer 14(9): 28, 30, 32. 1951. South. Lumberman

183(2291): $38-39$. 1951.

Richards, C. A., and Chidester, M. S.

The effect of Peniophora gigantea and Schizophyllum commune on strength of southern yellow-pine sapwood. Amer. Wood Preservers Assoc. Proc. 36: $24-31$. 1940 .

Sakornbut, Songe Sook

Differentiation of woods of southern pines by chemical means. Unpublished thesis, Duke Univ. 1948.

Scheffer, Theodore C., and Lindgren, Ralph M.

Stains of sapwood and sapwood products and their control. U. S. Dept. Agr.

Tech. Bul. 714. 124 pp. 1940.

Siggers, Paul V.

Slash-disposal methods in logging shortleaf pine. Southern Forest Expt.

Sta. Occas. Paper 42.5 pp. 1935. 
Snow, E. A.

Pine bark as a source of tannin. Jour. Amer. Leather Chemists Assoc. 44(7): 504-511. 1949.

Southern Forest Experiment Station

Interim log grades for southern pine. Southern Forest Expt. Sta. 18 pp. 1953.

Teesdale, C. H.

Relative resistance of various conifers to injection with creosote. U. S. Dept. Agr. Bul. 101. 43 pp. 1914.

Thelen, Rolf

Kiln drying handbook. U. S. Dept. Agr. Bul. 1136. 64 pp. 1923.

U. S. Forest Service

Shortleaf pine. U. S. Dept. Agr. Forest Serv. Trade Bul. 18. 4 pp.

(No date).

Wells, S. D., and Rue, J. D.

The suitability of American woods for paper pulp. U. S. Dept. Agr. Bul. 1485. 102 pp. 1927. 


\section{FUNGUS DISEASES}

Rust cankers - Heartrot - Littleleaf -

Needle cast - Needle blight - Needle rusts -

Root rot - Effect of fire on decay.

Anderson, Paul J., et al.

Check list of diseases of economic plants in the United States. U. S. Dept. Agr. Bul. 1366. 112 pp. 1926.

Boggess, W. R., and Newman, R. R.

Occurrence of littleleaf disease of pine and its effects on forestry in

Alabama. Ala. Agr. Expt. Sta. Cir. 94. 11 pp. 1947.

Boggess, W. R., Swarthout, P. A., and Toole, E. R.

Results of the survey on littleleaf disease of southern pines in Alabama.

Ala. Agr. Expt. Sta. 15 pp. 1941.

Bramble, W. C., and Holst, E. C.

Fungi associated with Dendroctonus frontalis in killing shortleaf pines and their effect on conduction. Phytopathology 30: 881-899. 1940.

Buchanan, Thomas S.

Characteristics of the little-leaf disease of southern pine. Unpublished thesis, Yale Univ. 1943.

Campbell, W. A.

Phytophthora cinnamomi associated with the roots of littleleaf-diseased shortleaf pine. Plant Dis. Rptr. 32:472. 1948.

Campbell, W. A.

Relative abundance of Phytophthora cinnamomi in the root zones of

healthy and littleleaf diseased shortleaf pine. Phytopathology 39: 752-753.

1949.

Campbell, W, A.

Needle cast of southern pines. Forest Farmer 9(1): 4, 10. 1949.

Campbell, W. A.

Vertical distribution of Phytophthora cinnamomi in the soil under littleleafdiseased shortleaf pine. Plant Dis. Rptr. 35: 26-27. 1951.

Campbell, W. A.

Fungi associated with the roots of littleleaf diseased and healthy shortleaf pine. Phytopathology 41(5): 439-446. 1951.

Campbell, W. A., and Copeland, O. L., Jr.

Littleleaf disease of shortleaf and loblolly pines. U. S. Dept. Agr. Circ. 940. 41 pp. 1954.

Campbell, W. A., Copeland, O. L., Jr., and Hepting, George H.

Managing shortleaf pine in littleleaf diseased areas. Southeastern Forest

Expt. Sta. Paper 25. 12 pp. 1953. 
Copeland, O. L., Jr.

Relationship of soils to littleleaf disease in pine. Forest Farmer 8(4): 6 . 1949.

Copeland, O. L., Jr.

Some relations between soils and the littleleaf disease of pine. Jour.

Forestry 47(7): 566-568. 1949.

Copeland, O. L., Jr.

Root mortality of shortleaf and loblolly pine in relation to soils and

littleleaf disease. Jour. Forestry 50(1): 21-25. 1952.

Hedgcock, George G.

A key to the known aerial forms of Coleosporium occurring in the United

States and a list of the host species. Mycologia 20(2): 97-100. 1928.

Hedgcock, George G., and Siggers, Paul V.

A comparison of the pine-oak rusts. U. S. Dept. Agr. Tech. Bul. 978.

30 pp. 1949.

Hepting, George $\mathrm{H}$.

Eastern forest tree diseases in relation to stand improvement. U. S.

Emergency Conserv. Work Forestry Pub. 2. 26 pp. 1933.

Hepting, George H.

Littleleaf, the pine killer. Ala. Conservation 15: 3, 10. 1944.

Hepting, George $\mathbf{H}$.

Littleleaf - a shortleaf and loblolly pine problem. Amer. Forests

50(5): 244. 1944.

Hepting, George $\mathrm{H}$.

Reserve food storage in shortleaf pine in relation to littleleaf disease.

Phytopathology 35(2): 106-119. 1945.

Hepting, George $\mathrm{H}$.

Decay and staining of southern pine pulpwood. Paper Indus. and Paper

World 27(3): 379-382. 1945.

Hepting, George $\mathrm{H}$.

Littleleaf disease of pine: how to prevent its ravages. Plants \& Gardens n. s. $7(2)$ : 153-154. 1951 .

Hepting, George H., and Chapman, A. Dale

Losses from heart rot in two shortleaf and loblolly pine stands. Jour.

Forestry 36(12): 1193-1201. 1938.

Hepting, George H., and Cruikshank, J. W.

Littleleaf disease in South Carolina as determined by the forest survey.

Jour. Forestry 48(12): 837-839. 1950 
Hepting, George H., and Jemison, George M.

Cure for little leaf disease? Amer. Forests 56(11):20-22. 1950.

Hepting, George H., and Roth, Elmer R.

Pitch canker, a new disease of some southern pines. Jour. Forestry

44(10): $742-744$. 1946.

Jackson, L. W. R.

Root defects and fungi associated with the littleleaf disease of southern

pines. Phytopathology 35: 91-105. 1945.

Jackson, L. W. R.

Needle curl of shortleaf pine seedlings. Phytopathology 38: 1028-1029.

1948.

Jackson, L. W. R.

Effect of littleleaf disease on growth of shortleaf pine. Jour. Forestry

49(11): $778-779$. 1951.

Jackson, L. W. R.

Influence of littleleaf on quality of shortleaf pine seed. Phytopathology 42:

57-58. 1952 .

Jackson, L. W. R., and Zak, B.

Grafting methods used in studies of the littleleaf disease of shortleaf pine.

Jour. Forestry 47(11): 904-908. 1949.

Lamb, Howard

Rust canker diseases of southern pines. Southern Forest Expt. Sta. Occas.

Paper 72.7 pp. 1937.

Lamb, Howard, and Sleeth, Bailey

Distribution and suggested control measures for the southern pine fusiform rust. Southern Forest Expt. Sta. Occas. Paper 91.5 pp. 1940.

Roth, Elmer R., Buchanan, Thomas S., and Hepting, George H.

A five-year record of littleleaf on thirty-one plots. Bur. Plant Indus.,

Soils, Agr. Engin., Forest Path. Spec. Release 32. 9 pp. 1948.

Roth, Elmer R., Toole, E. R., and Hepting, George H.

Nutritional aspects of the littleleaf disease of pine. Jour. Forestry 46(8): 578-587. 1948.

Siggers, Paul V.

Weather and outbreaks of the fusiform rust of southern pines. Jour.

Forestry 47(10): 802-806. 1949 .

Siggers, Paul V., and Doak, K. D.

Little-leaf disease of shortleaf pines. Southern Forest Expt. Sta. Occas.

Paper 95. 5 pp. 1940.

Waterman, A. M.

Diplodia pinea, the cause of a disease of hard pines. Phytopathology 33(11):

1018-1031. 1943. 


\section{MENSURATION}

Tables for stands, yields, volume, and taper Site index curves - Converting factors for pulpwood Volume - Weight ratio of logs - Stacked and solid volume of pulpwood - Tree and log grades.

Buell, Jesse H.

Outside-bark form class volume tables for some southern Appalachian species. Appalachian Forest Expt. Sta. Tech. Note 53.76 pp. 1942.

Chandler, R. F., Jr., Schoen, P. W., and Anderson, D. A.

Relation between. soil types and the growth of loblolly pine and shortleaf pine in east Texas. Jour. Forestry 41(7): 505-506. 1943.

Chisman, H. H., and Schumacher, F. X.

On the tree-area ratio and certain of its applications. Jour. Forestry 38(4): $311-317.1940$.

Coile, T. S.

Soil productivity for southern pines. Part I - Shortleaf and loblolly pines. Forest Farmer 11(7): 10-11, 13. 1952.

Coile, T. S., and Schumacher, F. X.

Site index of young stands of loblolly and shortleaf pines in the Piedmont plateau region. Jour. Forestry 51(6): 432-435. 1953.

Corthell, Richard Eldon

A comparison of tree site index with site index estimated from the soil for young shortleaf pine stands. Unpublished thesis, Duke Univ. 1949.

Emmer, R. E.

Volume table for shortleaf pine. Central States Forest Expt. Sta. Tech. Note 42. 1941.

Fields, James Gordon

The relationship of stump height diameter to diameter breast high for

loblolly and shortleaf pine. Unpublished thesis, Univ. of Georgia. 1947.

Girard, James W.

Volume tables for Mississippi bottomland hardwoods and southern pines. Jour. Forestry 31(1): 34-41. 1933.

Hargreaves, L. A.

Relationship between density and basal area of natural shortleaf pine stands in the Georgia Piedmont. Unpublished thesis, Univ. of Georgia. (Abs.) Jour. Forestry 46(4): 318.1948. 
Lemieux, F.J.

Log rules, taper tables, and volume tables for use in the south. Jour.

Forestry 34(10): 970-974. 1936.

Matte, Lorenzo

Pulpwood volume tables for southeastern pines. Unpublished thesis, Duke

Univ. 1944.

McClay, T. A.

Lumber grade yields in the loblolly-shortleaf pine type by the southern

pine log grades. Southeastern Forest Expt. Sta. Paper 37. 12 pp. 1954.

McCormack, James F.

D.b.h. in relation to stump diameter at various heights for southern

yellow pines and hardwoods. Southeastern Forest Expt. Sta. Res. Note 43. 1953.

Mesavage, Clement

New tables for estimating board-foot volume of timber. South. Lumberman

173(2177): 153-156. 1946.

Mesavage, Clement

Board-foot volume tables for southern lumbermen. South. Lumberman

175(2201): 195-197. 1947.

Mesavage, Clement

Tables for estimating cubic-foot volume of timber. Southern Forest Expt.

Sta. Occas. Paper 111. 71 pp. 1947.

Mesavage, Clement, and Girard, James W.

Tables for estimating board-foot volume of timber. U. S. Dept. Agr.

Forest Serv. 94 pp. 1946.

Meyer, Walter $\mathrm{H}$.

Diameter distribution series in even-aged forest stands. Yale Univ.

School of Forestry Bul. 28. 105 pp. 1930.

Minor, C. O.

Form class volume tables for use in southern pine pulpwood timber

estimating. La. Agr. Expt. Sta. Bul. 445. 39 pp. 1950.

Patterson, A. E., and Colson, J. H.

The effect of compass direction on the measurement of diameter breast

high of shortleaf pine. Jour. Forestry 50(1): 31.1952.

Reineke, L. H.

Perfecting a stand-density index for even-aged forests. Jour. Agr. Res.

46(7): 627-638. 1933.

Rothacher, Jack S.

Percentage distribution of tree volume by logs. Jour. Forestry 46(2):

115-118. 1948.

Schumacher, F. X.

Stacked and solid volume of southeastern pulpwood. Jour. Forestry 44(8):

579-582. 1946. 
Southeastern Forest Experiment Station

Tree grades for loblolly and shortleaf pine. Southeastern Forest Expt. Sta.

Tech. Note 69. 13 pp. 1948. Forest Farmer 8(1): 7. 1948. South.

Lumberman 177 (2225): 107-109. 1948.

Southern Forest Experiment Station

Interim log grades for southern pine. Southern Forest Expt. Sta. 18 pp.

1953.

Turner, Lewis M.

Relation of stand density to height growth. Jour. Forestry 41(10): 766. 1943.

U. S. Forest Service

Volume, yield, and stand tables for second-growth southern pines.

U. S. Dept. Agr. Misc. Pub. 50. 202 pp. 1929.

U. S. Forest Service

Volume tables, converting factors, and other information applicable to commercial timber in the South. U. S. Forest Serv., Region 8, Div. State and Private Forestry. 49 pp. 1951.

Wahlenberg, W. G.

Methods of forecasting timber growth in irregular stands. U. S. Dept. Agr. Tech. Bul. 796. 56 pp. 1941. 


\section{EFFECT ON SOIL}

Chemical composition of litter - Effect on soil profiles Use as a soil builder - Effectiveness in erosion control.

Billings, William Dwight

The structure and development of old field shortleaf pine stands and certain associated physical properties of the soil. Ecol. Monog. 8(3): $437-499.1938$.

Broadfoot, W. M.

Soil and litter under pine plantations. Southern Forest Expt. Sta. South. Forestry Notes 55. pp. 3-4. 1948.

Coile, T. S.

Soil reaction and forest types in the Duke Forest. Ecology 14(4): 323-333. 1933.

Coile, T. S.

Distribution of forest tree roots in North Carolina Piedmont soils. Jour. Forestry 35(3): 247-257. 1937.

Coile, T. S.

Composition of the leaf litter of forest trees. Soil Sci. 43(5): 349-355. 1937.

Coile, T. S.

Forest soil fertility: influence of stand composition on nitrogen transformation in the surface soil. Soil Sci. Soc. Amer. Proc. 3:225-229. 1938.

Coile, T. S.

Effect of soil in the development of hardwood understories in pine stands of the Piedmont Plateau. Soil. Sci. Soc. Amer. Proc. 14: 350-352. 1950.

Coile, T. S.

Soil and the growth of forests. Advances in Agronomy 4:329-398. 1952 .

Gibbs, J. A.

Growth of tree plantings for erosion control in the southeastern region.

Iowa State Col. Jour. Sci. 22(4): 371-386. 1948.

Jemison, George M.

Effect of litter removal on diameter growth of shortleaf pine. Jour.

Forestry 41(3): 213-214. 1943.

Mattoon, Wilbur R.

Shortleaf and loblolly pine litter and humus a valuable fertilizer. U. S.

Dept. Agr., Forest Worker 5(2): 14-15. 1929. 
Meginnis, H. G.

Using soil-binding plants to reclaim gullies in the South. U. S. Dept. Agr. Farmers' Bul. 1697. 18 pp. 1933.

Meginnis, H. G.

Tree planting to reclaim gullied lands in the South. Jour. Forestry 31(6): 649-656. 1933.

Meginnis, H. G.

Soil-collecting trenches as substitutes for temporary check dams in reforesting gullies. Jour. Forestry 37(10): 764-769. 1939.

Metz, L. J.

Calcium content of hardwood litter four times that of pine; nitrogen double. Southeastern Forest Expt. Sta. Res. Note 14. 1952.

Metz, L. J.

Weight and nitrogen and calcium content of the annual litter fall of forests in the South Carolina piedmont. Soil Sci. Proc. 16(1): 38-41. 1952.

Schavilje, Joseph P.

Reclaiming Illinois strip mined coal lands with trees. Jour. Forestry 39(8): $714-719.1949$. 


\section{EFFECT OF FIRE}

Effect on growth, stands, cull, mortality and plant succession - Use of prescribed fire.

Burns, Joe Dae

Some effects of forest fires on mortality and growth of certain species of southern pines. (Abs.) Jour. Forestry 47(7): 554. 1949.

Craighead, F. C., and St. George, R. A.

Some effects of fire and insect attack on shortleaf pine. Forest Worker $4(2): 11-12$. 1928.

Folweiler, A. D.

The place of fire in southern silviculture. Jour. Forestry 50(3): 187-190. 1952.

Garren, Kenneth $\mathrm{H}$.

Effects of fire on vegetation of the southeastern United States. Bot. Rev. $9(9)$ : $617-654$. 1943 .

Jemison, George M.

Effect of single fires on the diameter growth of shortleaf pine in the southern Appalachians. Jour. Forestry 41(8): 574-576. 1943.

Little, S., and Moore, E. B.

The ecological role of prescribed burns in the pine-oak forests of southern New Jersey. Ecology 30(2): 223-233. 1949.

Little, S., and Moore, E. B.

Effect of prescribed burns and shelterwood cutting on reproduction of shortleaf and pitch pine. Northeastern Forest Expt. Sta. Paper 35. 11 pp. 1950 .

Oosting, Henry J.

Comparative effect of surface and crown fire on the composition of a loblolly pine community. Ecology 25: 61-69. Jan. 1944.

Perry, George S.

Recovery of shortleaf and Virginia pines after forest fire. Tenn. Valley Authority Dept. For. Relations. Tech. Note 3. 1942.

Somes, H. A., and Moorhead, G. R.

Prescribed burning does not reduce yield from oak-pine stands of southern New Jersey. Northeastern Forest Expt. Sta. Paper 36. 19 pp. 1950.

Wyman, Lenthall

Results from sample plots in southern pines experiments. Jour. Forestry 20(7): $780-787.1922$. 


\section{INSECT ENEMIES \\ Borers - Bark beetles - Sawflys - Tip moths}

Beal, J. A.

Mortality of reproduction defoliated by the red-headed pine sawfly

(Neodiprion lecontei Fitch). Jour. Forestry 40(7): 562-563. 1942.

Caird, Ralph W.

Physiology of pines infested with bark beetles. Bot. Gaz. 96(4): 709-733.

1935.

Craighead, F. C., and St. George, R. A.

Some effects of fire and insect attack on shortleaf pine. Forest Worker 4(2): $11-12$. 1928.

Hetrick, L. A.

Some observations of Ips beetle attack on pine trees. Jour. Econ. Ent. 35(2): 181-183. 1942 .

Huckenpahler, B. J.

Loblolly best in north Mississippi despite tip moth and webworm. Jour. Forestry 51(9): 640. 1953.

Johnston, H. R., and Eaton, C. B.

Tests with various chemicals for the control of white grubs in forest

nurseries of the Carolinas. Jour. Rorestry 40(9): 712-721. 1942.

Kowal, R. Joseph

Pine sawfly in southern Arkansas. Forest Farmer 8(2): 3, 10.1948.

Lee, Robert E.

The role of insects in deterioration of dead loblolly and shortleaf pines.

Unpublished thesis, Duke Univ. 1951.

Middleton, William

A sawfly injurious to young pines. U. S. Dept. Agr. Farmer's' Bul. 1259.

6 pp. 1922. Rev. 1927.

Mortimer, M. F.

The life history and control of the pine tip moth (Rhyacionia frustrana

Comstock) (family Tortricidae) at Nashville, Tennessee. Tenn. Acad. Sci.

Jour. 16(2): 190-206. 1941.

Ramsey, H.

Fauna of pine bark. Jour. Elisha Mitchell Sci. Soc. 57(1):91-97. 1941.

St. George, R. A., and Beal, J. A.

The southern pine beetle. U. S. Dept. Agr. Farmers'Bul. 1586. 18 pp. 1929.

Wakeley, Philip C.

Preliminary observations on the pine tip moth (Rhyacionia frustrana Comst.)

on southern pines. 4th Internatl. Cong. Ent. Proc. 2:865-868. 1928.

Wakeley, Philip C.

Notes on the life cycle of the Nantucket tip moth Rhyacionia frustrana Comst.

in southeastern Louisiana. Southern Forest Expt. Sta. Occas. Paper 45.

8 pp. 1935. 


\section{GENETICS}

Natural variation - Effect of source of seed on growth Hybridization - Inheritance of characteristics Flower production - Vegetative propagation

Downs, Albert A.

Choosing pine seed trees. Jour. Forestry 45(8): 593-594. 1947.

Jackson, L. W. R., and Zak, B.

Grafting methods used in studies of the littleleaf disease of shortleaf pine. Jour. Forestry 47(11): 904-908. 1949.

McKinnon, A. D.

Development of southern pines in Auckland conservancy. New Zealand Jour. Forestry 5(2): 127-132. 1945. Forestry Abs. 8(2): 226.1946.

Minckler, Leon S.

Effect of seed source on height growth of pine seedlings. Jour. Forestry 48(6): $430-431$. 1950 .

Minckler, Leon S.

Southern pines from different geographic sources show different responses to low temperatures. Jour. Forestry 49(12): 915-916. 1951.

Perry, George S., and Coover, C. A.

Seed source and quality. Jour. Forestry 31(1): 19-25. 1933.

Righter, F. I.

Early flower production among the pines. Jour. Forestry 37(12): 935-938. 1939.

Stockwell, Palmer

Pine breeding today. South. Lumberman 177(2225): 279-281. 1948.

Wakeley, Philip C.

How seed source and seedling stock affect reforestation. Forest Farmer 12(2): 16, 28. 1952 .

Wakeley, Philip C.

Progress in study of pine races. South. Lumberman 187(2345): 137-140. 1953.

Weidman, R. H.

Trees in the Eddy Arboretum. California Forest and Range Expt. Sta. Note 53. 8 pp. 1947.

Zak, B.

Importance of resin in the grafting of shortleaf pine. Unpublished thesis,

Duke Univ. 1949. 
Genetics

Zak, B.

Developing littleleaf resistant shortleaf pine. South. Lumberman 187(2345): 147-149. 1953.

Zobel, B. J.

Are there natural loblolly-shortleaf pine hybrids? Jour. Forestry 51(7): 494-495. 1953. 


\section{AUTHOR INDEX}

All authors, senior and junior, are listed in alphabetical order. The numbers refer to the pages on which the citations appear.

Allen, John C. , 30

Anderson, D. A., 21, 48

Anderson, Paul J., 45

Anon. , 3, 39

Ashe, W. W. , 6, 9, 39

Attridge, J. Milton, 30

Auten, J. T., 20, 30

Baker, Frederick S., 9, 20

Barrett, Leonard I. , 9, 20, 30

Barton, Lela V., 20, 30

Beal, J. A., 9, 54

Becton, W. R., 20, 30

Beilmann, August P., 3

Berkeley, E. E., 39

Betts, H. S. , 3, 39

Billings, William Dwight, 20, 51

Boggess, W. R., 9, 10, 20, 30, 45

Bond, W. E., 10, 17

Bramble, W. C., 20, 45

Bray, Mark W. , 39

Brinkman, K. A., 30

Broadfoot, W. M., 20, 30, 51

Browne, F. L., 39

Bruce, David, 12

Buchanan, Thomas S., 17, 45, 47

Buckholz, J. T., 21

Buckman, Stanley, 39

Buell, Jesse H. , 10, 48

Buell, Murray F., 21

13ull, Henry, 10, 11, 39

Burns, Joe Dae, 11, 53

Burns, P. Y., 26, 34

Butts, Dorothy, 21

Byram, G. M., 11. 21

Cain, S. A., 21

Cain, L. G., 21

Caird, Ralph W. , 21, 54

Cameron, F. K., 21, 40

Campbell, W. A., 11, 45

Cantlon, J. E., 21

Chamberlin, H. H. , 11

Chandler, R. F., Jr., 21, 48

Chapman, Arthur G., 11, 16, 21, 31, 35

Chapman, A. Dale, 13, 39, 46

Chapman, H. H. , 11
Chen, W. -H, W. , 21, 40

Chidester, G. H. , 40

Chidester, M. S., 43

Chisman, H. H., 21, 48

Clark, Harry Dale, Jr., 21, 31

Clark, Stuart F., 11, 21

Coile, T. S., 11, 14, 21, 22, 25, 48,51

Colson, J. H. 49

Cook, Richard C. , 40

Coover, C. A., 36, 55

Copeland, O. L., Jr., 11, 22, 23, 45,46

Corthell, Richard Eldon, 23, 48

Cossitt, F. M., 31

Craig, Ronald B., 3

Craighead, F. C., 53, 54

Cruikshank, J. W., 3, 4, 6, 11 , 23

Cummings, William H., 11, 23, 31

Curran, C. E., 11, 40

Davidson, Ross W., 40

Davis, E. M., 40

Dawson, R. F., 28, 36

Demmon, E. L., 40

Deitschman, G. H., 14, 25, 27, 35

Detwiler, Samuel B., 4

Diftler, Nathan, 23

Dingle, R. W., 12, 31

Doak, K. D., 47

Doolittle, W. T., 11, 21

Downey, E. J., 40

Downs, Albert A., 20, 31, 35, 55

Duerr, W. A., 4, 7

Dunlap, Frederick, 12

Eaton, C. B. , 33, 54

Eldredge, I. F., 4, 7, 8

Emmer, R. E., 12, 48

Evans, Thomas C., 4, 5, 
F aulks, E. 13., 4

Fernow, B. E., 40

Ferrell, William K., 23, 31

Fields, James Gordon, 48

Finn, Raymond F., 23, 31

Flick, Frances J., 12

Folweiler, A. D., 12, 53

Forbes, R. D., 12, 40

Forest Products Laboratory, 4, 40

Freas, A. D., 41

Frothingham, E. H., 4

Garin, G. I., 12, 31

Garland, H., 23, 41

Garren, Kenneth H., 23, 53

Garver, R. D. 12

Ribbs, J. A., 12, 23, 32, 51

Girard, James W., 12, 15, 48, 49

Grabow, Rudolph H., 41

Grano, C. X., 12, 13, 23, 32

Greaves, 13., 4

Gregory, G. R., 41

Guttenburg, S., 13

Hahn, Vernon W., 24, 32

Haines, W. H. B., 41

Hall, William L., 13, 24

Hargreaves, L. A., 13, 48

Hamilton, S. W. , 32

Harper, R. M. , 4, 5

Hayes, R. W. , 11

Hebb, Edwin A., 11

Hedgecock, George G. , 46

Hepting, George H. , 11, 13, 17, 24, 28 $41,45,46,47$

Hetrick, L. A., 13, 54

Hicks, W. T., 5

Hobbs, C. H., 24, 32

Hobbs, James E., 24, 32

Holst, E. C., 20, 45

Huberman, M. A., 13, 24, 32

Huckenpahler, B. J., 13, 24, 28, 32, 54 McKinnon, A. D., 34, 55

Hunt, Francis M., 24, 32

Jackson, L. W. R., 24, 33, 47, 55

James, L. M., 5

Jemison, George M., 13, 14, 24, 47,

51,53

Johnston, H. R., 33, 54

Johnston, John P., 24, 33

Judson, George M., 11
Kellogg, L. F., 14, 41

Kirkland, Burt P., 17

Kittredge, J., 25

Koehler, Arthur, 5, 14, 41

Korstian, Clarence F., 14, 25, 33

Kowal, R. Joseph, 54

Kozlowski, Theodore Thomas, 14, 25

Kramer, Paul J., 25, 27, 33, 36

Kuenzel, J. G. , 14, 41

Kurth, E. F., 41

Lamb, Howard, 33, 47

Lane, R. D. , 14

Lange, Keith D. , 14, 25

Larson, Robert W., 5

Lee, Robert E., 54

Lemieux, F. J., 14, 49

Ligon, W. S. , 23, 32

Liming, Franklin G., 5, 14, 25, 30, 33

Limstrom, G. A., 14, 25

Lindgren, Ralph M., 14, 42, 43

Little, S. , 25, 33, 53

Lorenz, R. W., 10

Lotti, Thomas, 5

Lowe, E. N., 5

Lynch, D. W., 26, 33

MacNaughton, W. G. , 42

Mann, William F., Jr., 15, 26, 34

Marckworth, Gordon D., 15

Markwardt, L. J., 42

Marshall, Robert, 26, 34

Maryland State Board of Forestry, 5

Mathewson, J. S. , 42

Matte, Lorenzo, 15, 49

Mattoon, Wilbur R., 5, 15, 26, 42, 51

McClay, T. A., 42, 49

McCormack, James F., 5, 6, 49

McCulley, R. D. , 15

McDermott, R. E., 26, 34

McGovern, J. M. , 40

McLintock, Thomas F., 34

McMillan, F. W., 10

McNaughton, C. C. , 40

McQuilkin, W. E., 26, 34

Meginnis, H. G., 34, 52

Mesavage, Clement, 15, 49

Metz, L. J., 52

Meyer, Walter H., 15, 49

Middleton, William, 54 
Miller, Frank J., 26, 34

Miller, P. R. , 26, 35

Miller, R. H., 12

Minckler, Leon S., 15, 16, 26, 27 35,55

Minor, C. O., 16, 49

Moberg, T. R., 16

Mohr, Charles, 6

Moore, E. B., 25, 27, 33, 35, 53

Moorhead, G. R., 18, 53

Morbeck, George C., 42

Morrill, G. E., 4

Mortimer, M. F., 54

Munns, E. N. , 6

Myer, J. E., 42

Nelson, M. L., 27, 35, 36

Nelson, Ralph M., 4

Nelson, T. C., 27, 36

Newlin, J. A., 42

Newman, R. R., 10, 45

Oosting, Henry J., 25, 27, 33, 36, 53

Ordel, Arthur W., Jr., 16

Ostrom, Carl E., 27, 36

Patterson, A. E., 49

Paul, Bens on $\mathrm{H}_{\text {. , } 16,43}$

Perry, George S. , 6, 16, 27, 36 53,55

Person, H. L., 41

Pessin, L. J., 27

Pinchot, Gifford, 6

Ramsey, H., 54

Record, Samuel J., 6

Reed, John F., 28

Reineke, L. H., 49

Reynolds, R. R., 13, 16, 17, 19, 36,43

Richards, C. A., 43

Richter, F. I., 9, 28, 55

Roberts, E. V., 6

Roth, Elmer R., 17, 28, 47

Rothacher, Jack S., 17, 49

Routein, J. B., 28, 36

Rue, J. D. , 44

Sakornbut, Songe Sook, 43

Sample, L. A., 11

Schavilje, Joseph P., 36, 52

Scheffer, Theodore C., 39, 42, 43
Schoen, P. W., 21, 48

Schopmeyer, C. S., 28, 36

Schumacher, F. X., 17, 21, 22, 48, 49

Seizert, B. F., 25, 33

Shaw, G. R., 6

Siggers, Paul V., 18, 43, 46, 47

Siggins, Howard W., 36

Sleeth, Bailey, 47

Smith, Lloyd, 18, 28

Snow, E. A., 44

Somes, H. A., 18, 53

Southeastern Forest Experiment Station, 6, 18, 50

Southern Forest Experiment Station $6,7,18,44,50$

Spillers, A. R., 7

St. George, R. A., 28, 53, 54

Sternitzke, H. S., 7

Stockwell, Palmer, 55

Stoehr, Henry A., 28

Stone, Earl L., Jr., 28

Stone, Margaret H. 28

Swarthout, P. A., 30, 45

Teesdale, G. H., 44

Thelen, Rolf, 44

Toler, A. D., 4

Toole, E. R., 28, 45, 47

Turner, Lewis M., 18, 28, 29, 36, 50

U. S. Forest Service, 18, 44, 50

U. S. Tennessee Valley Authority, 7

Vaux, H. J., 12

Voigt, G. K., 29, 38

Wackerman, A. E., 18

Wahlenberg, W. G. , 19, 29, 50

Wakeley, Philip C., 19, 29, 36, 37, 54,55

Ward, G. B., 8

Waterman, A. M. , 47

Watkins, Virgil G., 19, 37

Weddell, D. J., 19, 29, 38

Weidman, R. H. , 8, 55

Wells, S. D., 44

Wenger, K. F., 29, 38

Wheeler, P. R., 19

Wherry, Edgar T., 29

Wilbur, Karl M., 25

Wilde, S. A., 29, 38

Williams, Edward B., 11 
Author Index

Williston, H. L., 29, 38

Wilson, Charles C., 29

Wilson, T. R. C., 42

Winters, R. K., 8

Wood, O. M. , 19, 38

Wyman, Lenthall, 19, 53

Zak, B., 47, 55, 56

Zobel, B. J., 56 